\title{
NOTE
}

\section{THE SPECIAL PROBLEM OF THE "YOUNGER OLDER WORKER": REVERSE AGE DISCRIMINATION AND THE ADEA}

\author{
Amy L. Schuchman
}

Mention the word discrimination, and most people picture a member of a minority class who an employer refuses to hire because of his or her protected class status. Mention the words age discrimination, and most people picture an older worker, someone with graying hair who has dedicated his or her adult life to the same job, but now was fired in favor of "a newer model" who, supposedly, has twice the productivity and half the cost. But mention the words age discrimination to the Sixth Circuit, and they paint a very different picture. Cline v. General Dynamics Land Systems, Inc. ${ }^{1}$ was the first case in the nation to explicitly allow younger employees to sue because of a claim that their employer treated older workers more favorably. Although one commentator has acknowledged that the issue of reverse age discrimination presents "a deep puzzle," dismissed the idea as "bizarre" because Congress's intent was allegedly "unmistakable."

This Note examines the phenomena of reverse discrimination in the context of age. Even under a plain language approach, the concept of reverse $1786(2003)$

1. Cline v. Gen. Dynamics Land Sys., Inc., 296 F.3d 466 (6th Cir. 2002), cert. granted, 123 S. Ct.

2. Michael C. Dorf, Equal Protection Incorporation, 88 VA. L. Rev. 951, 993 (2002).

3. Hamilton v. Caterpillar Inc., 966 F.2d 1226, 1227 (7th Cir. 1992). See also discussion infra Part I.B.

4. Recent Case, Sixth Circuit Permits Reverse Age Discrimination Suit to Proceed, 116 Harv. L. Rev. 1533, 1540 (2003). 
discrimination is complicated when it pertains to age because of the Age Discrimination in Employment Act's ("ADEA") limited protected class. ${ }^{5}$ Unlike Title VII, where anyone can sue if discriminated against on the basis of his or her race, color, religion, sex, or national origin, ${ }^{6}$ one must be forty or older to invoke the ADEA's protections. ${ }^{7}$ This limitation poses interesting questions. When Congress enacted the ADEA to curb age discrimination among "older" workers, did Congress mean "older" as "relatively older" than the worker who benefits from the discrimination, or did Congress mean "older" as those workers older than forty? If the ADEA does include reverse age discrimination, did Congress intend to include it? Regardless of what the statute actually says or what Congress intended, should the ADEA include reverse age discrimination? These questions raise even further conundrums. What is the correct way to interpret a statute? What is a legitimate purpose for anti-discrimination legislation? Should it accord age a neutral status or should it allow a preference for older workers? Finally, what does it actually mean to be "old"?

Although one may intuitively dismiss reverse age discrimination as irrational, absurd, or unintended by Congress, the issue is not as obviously resolvable as it first seems. Instead of automatically assuming the ADEA does not include reverse age discrimination, ${ }^{8}$ one can only resolve this legal quagmire after subjecting it to a multi-faceted analysis. Part I surveys the case law leading up to Cline, while Part II examines Cline itself. Part III evaluates Cline's holding and suggests what the outcome should be under three approaches: plain language, legislative history, and policy.

Part IV argues that while the plain language of the ADEA provides support for reverse age discrimination claims, these types of claims have serious policy implications. In light of the awkwardness of treating workers in their forties as "old" in today's society, Congress needs to re-study the problem of age discrimination to determine whether workers in the younger

\footnotetext{
5. 29 U.S.C. $\S \S 621-634$ (2003).

6. 42 U.S.C. $\$ 2000 \mathrm{e}-2(2003)$.

7. 29 U.S.C. $\S 631$ (a) (2003).

8. Interestingly, until recently, no commentators have discussed the topic of reverse age discrimination at length. Many just assume or accept at face value that reverse age discrimination is not cognizable. Since the Cline decision, there have been several student notes that delve into the topic. See Recent Case, supra note 4, at 1533; Aaron J. Rogers, Note, Discrimination Against Younger Members of the ADEA's Protected Class, 89 Iowa L. Rev. 313 (2003); Tracey A. Cullen, Note, Reverse Age Discrimination Suits and the Age Discrimination in Employment Act, 18 St. John's J.L. Comm. 271 (2003); Amanda Zaremba, Note, The ADEA and Reverse Age Discrimination: The Realities and Implications of Cline v. General Dynamics Land Systems, Inc., 72 U. CIN. L. REv. 389 (2003).
} 
end of the protected spectrum are affected by age discrimination to a substantially similar extent as workers in the older end. If they are not, this is an indication that reverse discrimination claims should not be cognizable. If they are, then the Supreme Court should adopt the following approach to analyze age discrimination claims. If an age distinction seems arbitrary, in recognition of the differences between age discrimination and other forms of discrimination, and the rationality of some economically based decisions based on age, the Supreme Court should allow employers to have the opportunity to explain why granting greater benefits to older workers is reasonable.

\section{State of the Law Before Cline}

\section{A. The Concept of Reverse Age Discrimination}

The Age Discrimination in Employment Act makes it unlawful for employers "to fail or refuse to hire or to discharge any individual or otherwise discriminate against any individual with respect to his compensation, terms, conditions, or privileges of employment, because of such individual's age." Under Title VII, anyone in the protected classes can sue. ${ }^{10}$ The ADEA, however, expressly limits the protected class to those individuals who are at least forty years of age. ${ }^{11}$

Members of minority groups, such as women or African-Americans, are the typical victims of discrimination. ${ }^{12}$ Title VII, however, also stands for the principle that employers should not subject any individual to an adverse employment action based on membership in a protected class..$^{13}$ For example, a white male could sue under Title VII if the employer did not hire him because the employer prefers black females. ${ }^{14}$ The term reverse discrimination appears to refer to these types of situations - where a plaintiff, who ordinarily belongs to a class that benefits from discrimination (i.e., white males), is discriminated against based on his or her majority class status.

9. 29 U.S.C. $\S 623(\mathrm{a})(1)(2003)$.

10. 42 U.S.C. $\S 2000 \mathrm{e}-2(2003)$.

11. 29 U.S.C. $\S 631$ (a) (2003).

12. See Harding v. Gray, 9 F.3d 150, 153 (D.C. Cir. 1993).

13. See, e.g., McDonald v. Santa Fe Trail Transp. Co., 427 U.S. 273, 279-80 (1976) (stating that Title VII protects whites as well as persons of color).

14. See id. 
Since the ADEA only protects individuals forty or over, it is an unsettled legal issue whether the ADEA encompasses reverse age discrimination claims. A reverse age discrimination claim would look something like this: a younger protected class member, i.e. a "younger older person" who is at least forty years of age, is discriminated against in favor of an older protected class member, i.e., an "older older person." ${ }^{15}$ While most courts have refused to recognize this type of claim, the Sixth Circuit in Cline v. General Dynamics Land Systems, Inc. ${ }^{16}$ took the unprecedented step of doing so.

\section{B. Cases Holding No Reverse Age Discrimination Under the ADEA}

Before Cline, virtually all courts refused to recognize a claim of reverse age discrimination. For example, although the plaintiffs in Karlen v. City Colleges of Chicago alleged their employer's early retirement plan discriminated against them in favor of older workers, the Seventh Circuit stated in dicta that "Title VII protects whites and men as well as blacks and women, but the Age Discrimination in Employment Act does not protect the young as well as the old, or even, we think, the younger against the older."17 If workers aged forty or older but younger than the eligibility age for early retirement benefits could claim discrimination, "early retirement plans would effectively be outlawed, and that was not the intent of the framers of the Age Discrimination in Employment Act." ${ }^{18}$ If one views the incentives employers give to older workers to retire as discrimination against those between forty

15. When this Note refers to workers aged forty and over as "older" workers, it is not because this author believes individuals forty and older are "old." Congress has made the determination that "older" workers are disadvantaged in employment, see 29 U.S.C. § 621(a), and has limited the prohibitions in the act to individuals who are at least forty years of age. See 29 U.S.C. § 631(a).

16. Cline v. Gen. Dynamics Land Sys., Inc., 296 F.3d 466 (6th Cir. 2002), cert. granted, 123 S. Ct. 1786 (2003).

17. Karlen v. City Colls. of Chicago, 837 F.2d 314, 318 (7th Cir. 1988); see also Schuler v. Polaroid Corp., 848 F.2d 276, 278 (1st Cir. 1988) (holding that the ADEA "does not forbid treating older persons more generously than others").

18. Karlen, 837 F.2d at 318. Since Karlen, Congress has amended the ADEA to allow a minimum age to be set for the attainment of early retirement benefits. The Older Workers Benefit Protection Act, Pub. L. No. 101-433, 104 Stat. 978 (1990) (codified as amended at 29 U.S.C. $§ 623(l)(1)(A)(2003)$ ). Since the passage of the Older Workers Benefit Protection Act ("OWBPA"), courts have not allowed younger employees in the protected class to invoke the ADEA if they are contesting more favorable benefits given to older workers in a pension plan as an incentive to retire early. See, e.g., Dittman v. Gen. Motors Corp., 941 F. Supp. 284, 287 (D. Conn. 1996) (noting that if the ADEA did not allow a minimum age to be set for the attainment of benefits under an early retirement plan, these types of "plans would effectively be outlawed"); Stone v. Travelers Corp., 58 F.3d 434, 437 (9th Cir. 1995) (same). 
and the eligibility age, the "employer could [only] be confident of escaping liability . . by allowing retirement at age $40 .{ }^{.19}$

Hamilton v. Caterpillar Inc. extended the philosophy in Karlen. ${ }^{20}$ In negotiations with its union, the defendant employer, Caterpillar Inc., agreed to implement a Special Early Retirement Program if two of its plants closed. ${ }^{21}$ Under the former pension plan, workers aged sixty or older with ten years of service were entitled to early retirement benefits. ${ }^{22}$ Workers ages fifty-five or older were able to add their years of service to their age; if the total exceeded eighty-five, they too were entitled to early retirement benefits. ${ }^{23}$ The new agreement extended early retirement benefits to workers ages fifty or older with ten years of service. ${ }^{24}$

After Caterpillar closed two plants, Hamilton brought a class action against Caterpillar, alleging that the program violated the ADEA.${ }^{25}$ According to the court:

The substance of the claim is more than a little bizarre: Hamilton and the other members of his class are between the ages of 40 and 50; they had ten years of service when the plants closed; and they are suing Caterpillar because they were too young to qualify for early retirement benefits. ${ }^{26}$

Hamilton argued age discrimination is like race or sex discrimination, and like those types of discrimination, it should cut both ways. ${ }^{27}$ The court found this argument to be facially "implausible" since "[a]ge is not a distinction that arises at birth. Nor is age immutable (leaving claims of plastic surgeons aside). ${ }^{28}$ It also argued that if the ADEA really meant to prevent reverse age discrimination, it would not make sense to limit the protected class to those forty and older." "To illustrate the point, imagine that only racial minorities and women could bring suit under Title VII. If Title VII so limited the plaintiff class, we would be unlikely to read that statute to prohibit reverse discrimination either." ${ }^{30}$

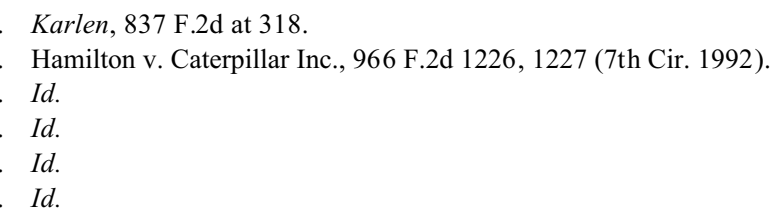


The court acknowledged that the Equal Opportunity Employment Commission ("EEOC") has promulgated a regulation that supports claims of reverse age discrimination. ${ }^{31}$ The regulation states:

It is unlawful in situations where this Act applies, for an employer to discriminate in hiring or in any other way by giving preference because of age between individuals 40 and over. Thus, if two people apply for the same position, and one is 42 and the other 52 , the employer may not lawfully turn down either one on the basis of age, but must make such decision on the basis of some other factor. ${ }^{32}$

The court then conceded that there is support for Hamilton's position in the ADEA's language itself. ${ }^{33}$ "Phrases like 'because of such individual's age,' 'on the basis of such individual's age,' or 'because of his age' lend themselves to an interpretation that prohibits use of age as a factor, period. ${ }^{.34}$ In addition, the ADEA's statement of purpose says that the Act is trying "to prohibit arbitrary age discrimination in employment. ${ }^{, 35}$

Nevertheless, the court did not find the regulation or the statute persuasive. The court argued that " $[t]$ here is no evidence in the legislative history that Congress had any concern for the plight of workers arbitrarily denied opportunities and benefits because they are too young." ${ }^{36}$ It argued that only older workers have invoked the EEOC regulation. ${ }^{37}$ Even if the regulation could support reverse discrimination, the court believed it "exceeds the scope of the statute. ${ }^{n 8}$ In addition, since the statutory language also refers to "older workers" and "older persons," the language referring generally to age is not broad enough to encompass all discrimination on the basis of age for those individuals forty and over. ${ }^{39}$ The court likened age discrimination to disability discrimination, believing that in both cases Congress was concerned about inaccurate stereotypes about abilities: "The young, like the

31. $I d$.

32. Id. at 1227-28 (quoting 29 C.F.R. § 1625.2(a) (1991)).

33. Id. at 1228 .

34. Id. (quoting 29 U.S.C. $\S \S 623(2)(1),(a)(2)$, (b), (c)(1) \& (c)(2) (2003)).

35. Id. (quoting 29 U.S.C. $§ 621(\mathrm{~b})(2003)$ ).

36. $I d$.

37. See id. "We have located only two references to regulation $1625.2 \ldots$ in the case law. In each case, the regulation is cited for the proposition that an older plaintiff may maintain a cause of action under the ADEA even if his replacement is over 40." Id. (citing La Montagne v. Am. Convenience Prod., Inc., 750 F.2d 1405, 1411 n.4 (7th Cir. 1984); Miller v. Lyng, 660 F. Supp. 1375, 1377-78 n.2 (D.D.C. 1987)). Since Hamilton, the Supreme Court has ruled that a plaintiff can meet a prima facie case of age discrimination even if the plaintiff's replacement was a member of the protected class. See O'Connor v. Consol. Coin Caterers Corp., 517 U.S. 308 (1996).

38. Hamilton, 966 F.2d at 1227.

39. Id. (quoting 29 U.S.C. $\S \S 621(\mathrm{a})(1),(\mathrm{a})(2), \&(\mathrm{a})(3)(2003))$. 
non-handicapped, cannot argue that they are similarly victimized." ${ }^{\prime 4}$ The court concluded: "Perhaps Congress should have written 'because such individual is older' or 'on the basis of such individual's advancing age,' but we are unwilling to open the floodgates to attacks on every retirement plan because Congress chose more graceful language." ${ }^{41}$

Since Hamilton, many courts have followed the reasoning of the Seventh Circuit. ${ }^{42}$ Accordingly, courts in the First,${ }^{43}$ Second, ${ }^{44}$ Fourth,${ }^{45}$ and Seventh Circuits $^{46}$ are unanimous: the ADEA simply does not encompass a claim of reverse age discrimination. ${ }^{47}$

\section{Id.}

41. Id.

42. See Feigl v. Ecolab, Inc., No. 03-C2290, 2003 U.S. Dist. LEXIS 15886, at*8-10 (N.D. Ill. Sept. 11, 2003) (following Hamilton to uphold the discontinuation of retiree medical coverage for employees between the ages of forty and fifty); Lawrence v. Town of Irondequoit, 246 F. Supp. 2d 150, 161 (W.D.N.Y. 2002) (following Hamilton to uphold the discontinuation of retiree health benefits for retirees under the age of eighty); Parker v. Wakelin, 882 F. Supp. 1131, 1140-41 (D. Me. 1995) (following Hamilton to uphold an early retirement plan); Conn v. First Union Bank of Va., No. 94-0901-R, 1995 U.S. Dist. LEXIS 9242, at*3-7 (W.D. Va. Mar. 17, 1995) (following Hamilton to approve the employer's discontinuation of a life insurance policy benefit for employees under fifty-five).

43. Schuler v. Polaroid Corp., 848 F.2d 276, 278 (1st Cir. 1988).

44. Lawrence, 246 F. Supp. $2 \mathrm{~d}$ at 161.

45. Conn, 1995 U.S. Dist. LEXIS 9242, at *3-7.

46. Hamilton v. Caterpillar, Inc., 966 F.2d 1226, 1227 (7th Cir. 1992).

47. Courts in at least three other circuits have declined to squarely address whether reverse age discrimination claims are cognizable. See Stone v. Travelers Corp., 58 F.3d 434, 437 (9th Cir. 1995) (describing a reverse discrimination claim as "unusual" and affirming the district court's dismissal on a narrower ground); Edwards v. Bd. of Regents of the Univ. of Ga., 2 F.3d 382, 382-83 n.1 (11th Cir. 1993) (describing a reverse discrimination claim as unusual, but declining to decide whether, as a matter of law, the ADEA covers reverse discrimination where the facts did not support a claim of age discrimination for other reasons); Mahoneyv. Northwest Airlines Pension Plan, 2004 U.S. Dist. LEXIS 891, at *6-8 (D. Minn. Jan. 8, 2004) (declining to decide whether the ADEA allows reverse discrimination claims because statute specifically allowed pension plan at issue). 


\section{The Lone Case Supporting the Notion that the ADEA Encompasses Age Discrimination Against Younger Older Plaintiffs}

Before Cline, only one case, ${ }^{48}$ Mississippi Power \& Light Co. v. Local Union Nos. 605 \& 985, International Brotherhood of Electrical Workers, $A F L-C I O^{49}$ supported the notion that the ADEA does not allow employers to discriminate against "younger older" workers in favor of "older older workers." This case involved a dispute about a provision of a collective bargaining agreement between the plaintiff (the employer) and the defendants (the labor unions). ${ }^{50}$ If an employee of the plaintiff was disabled, between sixty and sixty-five years of age, and had obtained thirty years of service with the plaintiff, the provision allowed the employee to resist any attempt by the plaintiff to transfer him or her to a new work location. ${ }^{51}$ When the plaintiff transferred an eligible employee from a plant in Flora, Mississippi, to a plant in Madison, Mississippi, the defendants asked the plaintiff to return the

48. The court in Cline cites Rannels v. Hargrove, 731 F. Supp. 1214 (E.D. Pa. 1990) as a case that supports the notion of reverse age discrimination. Cline v. Gen. Dynamics Land Sys., Inc., 296 F.3d 466, 470 (6th Cir. 2002), cert. granted, 123 S. Ct. 1786 (2003). Rannels, however, involved a claim brought under the Age Discrimination Act, 42 U.S.C. $\S \S 6101-6107$ (2003). Rannels, 731 F. Supp. at 1216. As the court in Conn noted, "[o]ne of the grounds for the court's decision was that there was no limitation within the act being interpreted regarding the age of those being protected," whereas the ADEA limits its protections to those over forty. Conn v. First Union Bank of Va., No. 94-0901-R, 1995 U.S. Dist. LEXIS 9242, at *7 n.4 (W.D. Va. Mar. 17, 1995). Thus, much like various state courts which have interpreted their respective state anti-discrimination statutes to encompass reverse age discrimination claims, see Bergen Commercial Bank v. Sisler, 723 A.2d 944 (N.J. 1998), their reasoning is inapplicable because the statutes are fundamentally different from the ADEA because they do not restrict the plaintiff class by a cutoff age. There are, however, cases that have allowed "younger older" workers to claim that they have been discriminated against in favor of "older older" workers. These cases are limited in the support they provide because they only allow the claims to progress because of inferential evidence that the "older older" worker was hired as a defense to the "younger older" worker's age discrimination claim. See Greene v. Safeway Stores, Inc., 98 F.3d 554, 564 (10th Cir. 1996) (reversing and remanding a claim of a fifty-twoyear-old man where there is circumstantial evidence that his fifty-seven-year-old replacement was hired temporarily to ward off an age discrimination suit); see also Loeb v. Textron, Inc., 600 F.2d 1003, 1013 n.9 (1st Cir. 1979) ("The older replacement could have been hired, for example, to ward off a threatened discrimination suit.”); Alphin v. Sears, Roebuck \& Co., 940 F.2d 1497, 1501 (11th Cir. 1991) (reversing summary judgment in this special circumstance to allow the younger plaintiff to go forward where it appears the employer hired the older replacement as a scheme to eliminate both protected employees); Douglas v. Anderson, 656 F.2d 528, 533 (9th Cir. 1981) (citing Loeb in dicta).

49. Miss. Power \& Light Co. v. Local Union Nos. 605 \& 985, Int'1 Bhd. of Elec. Workers, 945 F. Supp. 980 (S.D. Miss. 1996), aff'd without opinion, 102 F.3d 551 (5th Cir. 1996).

50. Id. at 981 .

51. Id. at $981-82$. 
employee to the plant in Flora. ${ }^{52}$ After denying the grievance and claiming the action complied with the collective bargaining agreement, the plaintiff employer sought declaratory judgment to void the provision as facially violating the ADEA. ${ }^{53}$ The defendant unions claimed the provision was a valid bona fide seniority system and fell outside the scope of the ADEA. ${ }^{54}$ They also said it was an attempt to counter the effects of past discrimination by the plaintiff, who allegedly used to transfer older disabled employees to distant and inconvenient locations in order to force them into early retirement. $^{55}$

The court found that the provision in the collective bargaining agreement "on its face explicitly favors members of the protected age group between the ages of 60 and 65 over other members of the protected age group with respect to a benefit of employment. ${ }^{156}$ As an example, the court stated that a "disabled 50-year-old employee with 30 years of employment would not be entitled to remain at his present headquarters under [the provision] solely because he is not between the ages of 60 and 65." ${ }^{.57}$ The court concluded, "[b]ecause this provision against transferring is keyed to an employee's age, it is facially violative of the ADEA." 58 The court ultimately held that the provision was not a bona fide seniority plan under $\S \S 623(f)(1)$ or $(f)(2)$ of the ADEA. $^{59}$

Thus, the prior case law illustrates why the Cline case is controversial: since the passage of the ADEA, only one court and the EEOC have supported the notion (without directly authorizing reverse age discrimination suits) that age discrimination encompasses a situation where an employer favors older workers over younger workers when all of the workers are in the protected class. In addition, the courts declaring that the ADEA does not encompass reverse age discrimination used reasoning that is diametrically opposed to the reasoning of the majority in Cline, as the next section illustrates.

55. Id.

56. Id. at 985 .

57. Id.

58. Id.

59. Id. at 986 .
} 


\section{The Cline Decision}

\section{A. Facts}

The United Auto Workers, a union, and General Dynamics Land Systems, Inc., an employer, entered into a new collective bargaining agreement ("CBA") designed to take effect on July 1, 1997. ${ }^{60}$ The previous CBA required General Dynamics to provide full health benefits to all retired workers who had accumulated thirty years of seniority. ${ }^{61}$ The new CBA changed General Dynamic's obligations. ${ }^{62}$ They no longer had to offer full health benefits to employees upon retirement, except to those employees who were fifty years of age or older on July $1,1997 .^{63}$

\section{B. Procedural History}

Dennis Cline and 196 other employees of General Dynamics filed a claim with the EEOC. ${ }^{64}$ They obtained a determination from the EEOC that "the [new CBA] adversely affected General Dynamics employees who were between the ages of 40 and 49 on July 1, 1997.".65 The 197 employees then filed suit under the ADEA and the Ohio Civil Rights Act, Ohio Rev. Code $\S 4112.99 .^{66}$ Each plaintiff was a member of the ADEA's protected class because each was between the ages of forty and forty-nine on July $1,1997 .^{67}$

The plaintiffs divided themselves into three groups for the lawsuit. ${ }^{68}$ The first group consisted of 183 current employees who were no longer eligible for full health benefits upon retirement. ${ }^{69}$ The second group was composed of ten employees who retired prior to July 1, 1997, to receive full health benefits. ${ }^{70}$

60. Cline v. Gen. Dynamics Land Sys., Inc., 296 F.3d 466, 467-68 (6th Cir. 2002), cert. granted, 123 S. Ct. 1786 (2003).

61. Id. at 468 .

62. $I d$.

63. $I d$.

64. Id.

65. Id. at 467-68.

66. Id.

67. Id.

68. Id.

69. Id.

70. Id. 
The final group included three employees who were ineligible for full health benefits but retired anyway after July $1,1997 .{ }^{71}$

General Dynamics filed a motion to dismiss the plaintiffs' claims, arguing that age discrimination in favor of employees over the age of fifty did not violate the ADEA. ${ }^{72}$ The district court stated that "the CBA facially discriminates on the basis of age by creating two classes of employees: employees over the age of fifty, who are entitled to retiree health care benefits, and employees under the age of fifty, who are not." ${ }^{13}$ The court declared that the sole issue was "whether the ADEA permits this sort of 'reverse discrimination' whereby older workers receive favorable treatment relative to younger workers," when all of the workers are still in the protected class. ${ }^{74}$

The plaintiffs argued that they were not bringing a claim of reverse age discrimination. ${ }^{75}$ They argued rather that their claim was one of a wrongful denial of existing job benefits based on age. ${ }^{76}$ What mattered to the district court was whether employers could create a collective bargaining agreement that facially denied workers under fifty a benefit given to workers over fifty. ${ }^{77}$

The district court declared that they were not aware of any court ever holding that "a claim of reverse age discrimination is . . cognizable under [the] ADEA." 78 The court believed "[t]his is because Congress" purpose in

71. Id.

72. Cline v. Gen. Dynamics Land Sys., Inc., 98 F. Supp. 2d 846, 847 (N.D. Ohio 2000), rev'd, 296 F.3d 466 (6th Cir. 2002), cert. granted, 123 S. Ct. 1786 (2003). Since the legal tests are the same under the ADEA and the Ohio Civil Rights Code, the court analyzed the claims under the two statutes together. Id. at 848 n. 1 .

73. Id. at 848 .

74. Id.

75. $I d$.

76. Id. The plaintiffs tried to make a distinction between reverse age discrimination on one hand and discrimination based on solely an individual's age on the other. The Sixth Circuit maintained this distinction in its opinion, without much explanation as to the difference between the two types of discrimination. See Cline, 296 F.3d at 471. It appears a reverse discrimination claim is one where an employer specifically favors an older employee over a younger emp loyee, whereas discrimination based on age involves an employer arbitrarily treating an employee differently based solely on age, regardless of what that age is. In effect, discrimination on the basis of age could have the same result as a reverse age discrimination claim, i.e., an older employee treated more favorably than a younger employee. The difference may lie in the concept of animus (or at least preference for the favored age). Perhaps in a reverse discrimination context, the employer acts on its belief that older people are always more qualified or mature. Discrimination on the basis of age, on the other hand, may only encompass differences in treatment that are arbitrary or because of some other factor, such as cost. For simplicity, this Note uses the term reverse age discrimination generically throughout to apply to any situation where a younger protected class member is claiming that he or she was discriminated against in favor of an older protected class member.

77. Cline, 98 F. Supp. $2 \mathrm{~d}$ at 848.

78. Id. 
enacting [the] ADEA was to address the problems faced by older workers, not workers who suffer discrimination because they are too young." the court dismissed the case since the plaintiffs did not state any facts upon which they could prevail. ${ }^{80}$

\section{Judge Ryan's Majority Opinion}

At this stage, the outlook looked bleak for the plaintiffs. The case law was not on their side, and the district court had just weighed in on the side of courts denying claims of reverse discrimination. Nevertheless, the Sixth Circuit Court of Appeals accepted the appeal and reversed the district court in a two to one decision, holding that the ADEA did provide the plaintiffs with a cause of action. ${ }^{81}$

Reviewing the claim de novo, the court looked at the language of the statute to determine the intent of the legislature. ${ }^{82}$ The court stated, "where the statute's language is plain and unambiguous, there is no justification for resorting to legislative history to ascertain the lawmaker's intent - the words of the statute suffice." 83 What is actually stated in the law, not what the legislature intended, is what controls: "[S]tatutory provisions often go beyond the principal evil to cover reasonably comparable evils, and it is ultimately the provisions of our laws rather than the principal concerns of our legislators by which we are governed." ${ }^{44}$ Thus, "if a court thinks statutory language does not reflect what the court believes the legislators 'must have' intended, the court may not, under the guise of 'statutory interpretation,' rectify the problem by holding, in effect, that the legislators intended something other than what they declared." ${ }^{85}$ In effect, "it is not the Court's role to address perceived inadequacies in [a statute]" ${ }^{\prime 86}$ or adjust statutory language.

The court then interpreted the ADEA's language, starting with $\S 623(a)(1)$, which states that it is unlawful for employers "to fail or refuse to hire or to discharge any individual or otherwise discriminate against any individual with respect to his compensation, terms, conditions, or privileges

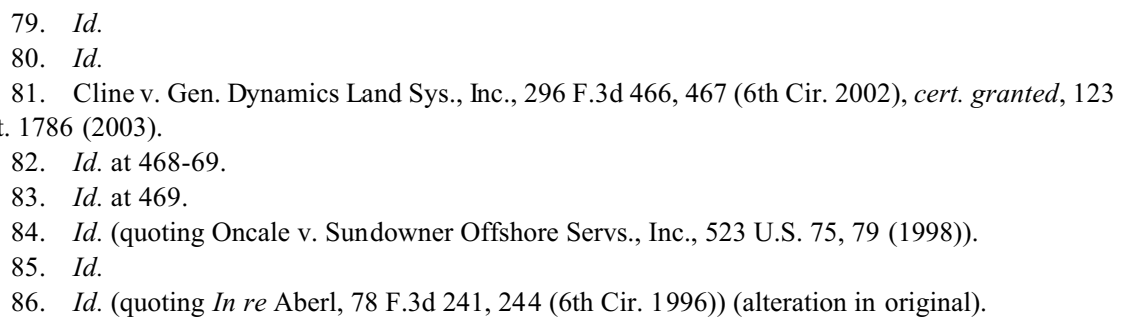


of employment, because of such individual's age." ${ }^{87}$ The court claimed that " $[\mathrm{t}]$ his language clearly and unambiguously forbids employers from defining the terms and benefits of 'any individual['s]' employment based solely on his or her age." ${ }^{" 88}$ Since Congress declared in $\S$ 631(a) that an individual must be at least forty years of age to be covered by the statute, "by the law's plain language, an employer may not discriminate against any worker age 40 or older on the basis of age." 89

The court refused to adopt the defendant's and district court's "interpretive reading" of the statute by holding that "the plain language of $\S 623(\mathrm{a})(1)$ and $\S 631$ (a) does not mean what it says when it refers to 'any individual,' but means, instead, 'older workers." 900 In effect, the court believed the provision prohibiting discrimination against an individual "because of such individual's age" applies to all workers over forty, not just workers who meet the additional requirement of also being older than another worker. ${ }^{91}$

The court then moved on to critique the Hamilton opinion and its reliance on legislative history. It recognized that Hamilton and a majority of courts refused to recognize causes of action for reverse discrimination but found that Hamilton and courts following its reasoning failed "to properly interpret the ADEA." 92 The court believed the Hamilton opinion "assigns far too much weight to the hortatory, generalized language of the Congress's Statement of Findings and Purpose in the ADEA." ${ }^{93}$ In addition, the court believed other courts reversed "the familiar rule that the more direct and specific language of a statute ordinarily trumps the more generalized." ${ }^{\prime 4}$

During the next stage in the opinion, the court marshaled arguments in support of its holding. It started by citing the Statement of Findings and Purpose:

[I]n the face of rising productivity and affluence, older workers find themselves disadvantaged in their efforts to retain employment, and especially to regain employment

87. Id. (quoting 29 U.S.C. $§ 623(a)(1)$ (2000)) (emphasis added by the court).

88. Id. As one commentator has pointed out, $\S 623(\mathrm{a})(1)$ "does not so clearly and unambiguously encompass employee benefit plans." Recent Case, supra note 4, at 1537. Section 623(a)(1) does not mention terms and benefits at all, but $\S 630(l)$, which the court does not discuss, does include employee benefit plans within $\S 623(\mathrm{a})(1)$. Id

89. Cline, 296 F.3d at 469 .

90. Id.

91. See id.

92. Id. at 470 .

93. Id.

94. $I d$. 
when displaced from jobs. It is therefore the purpose of this chapter to promote employment of older persons based on their ability rather than age; to prohibit arbitrary age discrimination in employment; to help employers and workers find ways of meeting problems arising from the impact of age on employment. ${ }^{95}$

It noted there is no definition of "older workers" or "older persons." "To hold, as the ADEA requires us to hold, that employment age discrimination against any worker at least 40 years of age is prohibited, does nothing to defeat the congressional intent to protect 'older workers' and 'older persons." 997 The court argued that each section of the ADEA could be easily reconciled. "In $\S 621$, Congress declared its intention to protect older workers, and in $\S 623$ and $\S 631$, it identified the older workers it intends to protect as 'any individual' age 40 or older." 98

The court then defended its holding by stating this situation was not reverse discrimination." "An action is either discriminatory or it is not discriminatory, and some discriminatory actions are prohibited by law." ${ }^{100}$ It presumed what the district court and others meant by the term "reverse discrimination" was a situation where victims are in the protected class but usually are the beneficiaries of discrimination against others. ${ }^{101}$ Nevertheless, the court again stated that courts cannot redraft anti-discrimination legislation to advance the court's own policies. ${ }^{102}$ Assuming arguendo that reverse discrimination is a legal concept, the court argued it does not apply to the situation such as this where workers in the protected class were denied a benefit due to their age. ${ }^{103}$ "[T] he protected class should be protected; to hold otherwise is discrimination, plain and simple." 104 Finally, the court noted that courts adopting the Hamilton holding take a position contrary to 29 C.F.R. $\S 1625.2(\mathrm{a}){ }^{105}$ "While a court can certainly interpret a statute and properly reach a different conclusion from a federal agency, we are persuaded that the EEOC's interpretation of the ADEA is a true rendering of the language."106

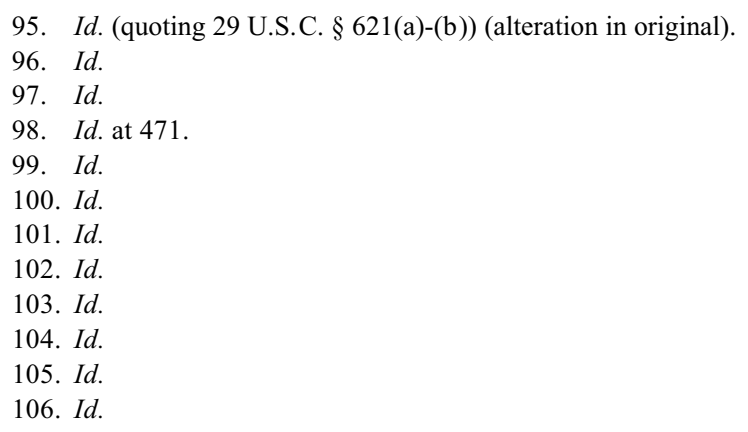


The court then applied the facts to its interpretation of the ADEA. It started by acknowledging that the "facts of this case are unusual and fall outside the typical ADEA claim, in that the plaintiffs were younger than the employees who were to receive health benefits upon retirement under the [new collective bargaining agreement]." 107 The court argued that just because some members of the protected class were beneficiaries of a discriminatory action that harmed other members, this did not "suspend" the statutory language that prohibits age discrimination against "any individual" within the protected class. ${ }^{108}$

Thus, the court held that since the ADEA expressly prohibits the denial of a protected employee's benefit solely on the basis of age, and since the new collective bargaining agreement denied a group of employees within the protected class a benefit based on their age, the ADEA prohibits the new collective bargaining agreement. ${ }^{109}$ The court concluded that "[i]f Congress wanted to limit the ADEA to protect only those workers who are relatively older, it clearly had the power and acuity to do so."110 Despite any policy justifications for holding otherwise, the court believed it was bound by the plain language of the statute and had "no occasion to look outside of the text." "111 Since it reversed the district court's ruling on the motion to dismiss, it remanded the case back to the district court. ${ }^{12}$

Thus, Judge Ryan gave a reasonable argument as to why the plaintiff's case was valid under the ADEA. By only focusing on the plain language, however, it left unanswered many questions. Judge R. Guy Cole, Jr. attempted to address these questions in the concurrence.

\section{Judge R. Guy Cole, Jr. 's Concurrence}

Judge R. Guy Cole, Jr. began his concurrence by stating that while he joined the majority opinion "based on the force of the plain language of the ADEA," he also "entertain[ed] serious doubts as to whether Congress specifically intended that the ADEA allow persons ages forty and over to recover for so-called reverse age discrimination." 113 He believed Congress

107. Id. at $471-72$.

108. $I d$. at 472 .

109. Id.

110. Id.

111. Id.

112. $I d$.

113. Id. at 472 (Cole, J., concurring). 
was most concerned with protecting older employees from discrimination in favor of younger employees. ${ }^{114}$ Nevertheless, he believed the language chosen by Congress, whether intended or not, prohibits age discrimination that favors older over younger protected employees. ${ }^{115}$

Judge Cole first reiterated that $\S 623$ and $\S 631$ of the ADEA "unambiguously prohibit using age as a basis for employment decisions involving persons ages forty and over." ${ }^{.16}$ He then claimed that a court in the Sixth Circuit could only look outside the text when a plain text reading leads to (1) ambiguity, (2) inconsistency with other provisions of the statute, (3) inconsistency with congressional intent, or (4) absurdity. ${ }^{117}$

Judge Cole believed there was no ambiguity within $\S 623$ and $\S 631$ and stated that the plain language of $\S 623$ and $\S 631$ was consistent with the other provisions of the statute. ${ }^{118} \mathrm{He}$ argued $\S 621$ (a)'s reference to "older workers" was "at most ambiguous because 'older workers' could also refer to that population of workers ages forty and over;" he concluded at worst that there was no definite inconsistency. ${ }^{119} \mathrm{He}$ also argued, in contrast to Hamilton, that the majority's reading of $\S 623$ and $\S 631$ did not render $\S 623(l)(1)(\mathrm{A})$ meaningless. ${ }^{120}$ Section $623(l)(1)(\mathrm{A})$ allowed employers to set minimum ages as a condition for eligibility in a pension plan. ${ }^{121}$ If the ADEA did not allow younger employees to sue, he believed the minimum age exception would be unnecessary since only younger employees would sue based on a minimum retirement age..$^{122}$

Furthermore, he also argued that there was no inconsistency with Congress's statutorily stated intent for enacting the ADEA. ${ }^{123}$ For example, one stated reason for enactment was "to promote employment of older persons based on their ability rather than age." 124 He contended, "when a forty-two year-old employee loses her job or benefits in favor of a fifty-two year-old employee due to her age, that termination is not based on her ability." 125

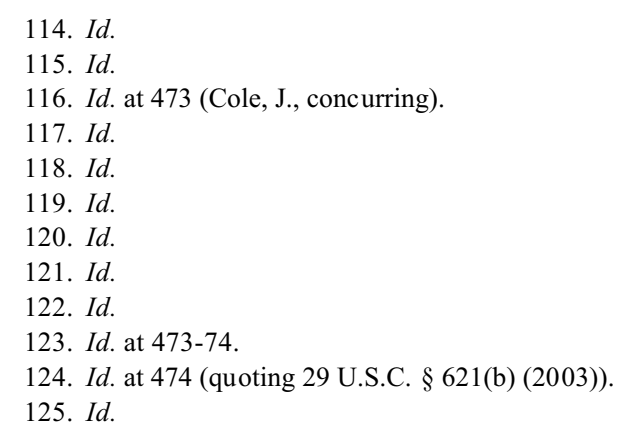


Finally, he argued that allowing reverse discrimination suits was "not absurd as either a matter of reason or of policy." 26 Congress was concerned that older workers would find themselves disadvantaged in efforts to find and keep employment because they usually earn higher wages. ${ }^{127}$ Permitting younger members of the protected "older" class is consistent with that finding. ${ }^{128}$ "For example, a fifty year-old employee is equally disadvantaged in retaining and regaining employment if he is age discriminated against in favor of a thirty year-old as if he is age discriminated against in favor of a sixty year-old." 129 In addition, many courts interpret state statutes to encompass reverse age discrimination, showing that they have not opened the floodgates to attacks on every retirement plan. ${ }^{130}$

Judge Cole's third reason for a separate concurrence is to reconcile the tension between the majority opinion and the Supreme Court's holding in O'Connorv. Consolidated Coin Caterers Corp. ${ }^{131}$ In Consolidated Coin, the Supreme Court had to determine whether a plaintiff had to be replaced by a person outside the protected class to satisfy the prima facie test used to prove indirect age discrimination under the ADEA. ${ }^{132}$ In that case, an employer replaced the fifty-six-year-old plaintiff with a forty-year-old. ${ }^{133}$ The Supreme Court held that it did not matter if the replacement was a member of the protected class as long as the replacement was substantially younger than the plaintiff. ${ }^{134}$ Although this was a direct evidence case, Judge Cole noted the impact of the substantially younger requirement in circumstantial evidence cases "implies that reverse age discrimination claims are not permitted under the ADEA because when discriminated against in favor of older workers, younger protected workers cannot prove that substantially younger persons were favored." "135

Although a "close call," Judge Cole contended that reverse age discrimination claims are permitted regardless of the substantially younger requirement. ${ }^{136}$ First, the Supreme Court was not confronted with a reverse

132. Id. (citing O'Connor v. Consol. Coin Caterers Corp., 517 U.S. 308, 312 (1996)).

133. Id. (citing Consol. Coin, 517 U.S. at 312 ).

134. Id. (citing Consol. Coin, 517 U.S. at 313).

135. $I d$.

136. Id. at 476 . 
discrimination claim. ${ }^{137}$ Second, the Consolidated Coin holding enables members within the protected class to sue when discrimination favors another member. ${ }^{138}$ Third, the Six th Circuit followed the same method as the Supreme Court by looking to the plain language of the text. ${ }^{139}$ "Moreover, had the Supreme Court also considered the question of reverse age discrimination in Consolidated Coin, [Judge Cole] believe[d] it would have expressed the fourth part of the prima facie test as requiring proof of 'substantial difference in age' as opposed to 'substantially younger."'140

Despite finding the result "counterintuitive," Judge Cole concluded that the "clarity with which Congress spoke" convinced him to join the majority opinion. ${ }^{141}$ His opinion addressed in more detail some of the anticipated objections to the holding. Nonetheless, Judge Glen M. Williams was not convinced and wrote a short dissent.

\section{E. Judge Glen M. Williams's Dissent}

Judge Glen M. Williams's dissent began by strongly declaring, "[w] hether you declare it 'reverse discrimination' or not, no court in the nation has recognized a claim for age discrimination under the ADEA when brought by younger workers within the protected class arguing that they were discriminated against in favor of older workers."142 Judge Williams acknowledged his approval of Hamilton, and stated that $\S 621$ refers to "older workers" and "older persons." 143 He believed "[t]hese references are, therefore, telling of Congress's intent to prohibit employers from discriminating against older workers, as opposed to younger ones."144 Judge Williams believed Congress did not intend to interfere with the collective bargaining process. ${ }^{145} \mathrm{He}$ also trusted that the older a person becomes the greater his or her needs become; therefore, a fifty-year-old may need more protection or benefits than a forty-year-old. ${ }^{146}$ Because of the majority's holding, he predicted a possible devastating effect on the collective bargaining

139. Id.

140. Id.

141. Id. at 476 .

142. Id. at 476 (Williams, J., dissenting).

143. Id.

144. $I d$.

145. Id.

146. Id. 
process, as the holding "call[ed] into question the validity of seniority and early retirement programs contained in collective bargaining agreements across the country. If such is allowed, bargaining for all workers, regardless of age, would suffer."147

Judge Williams's interpretation is in accordance with Hamilton and its progeny. ${ }^{148}$ His dissent raised general concerns with the majority's holding and its implications for society. The next section explores the strengths and weaknesses of the opinion, subjecting the notion of reverse age discrimination to analysis under three approaches: plain language, legislative history, and policy.

\section{Evaluation of Cline's Holding: Three Different Approaches}

Cline presents a legal conundrum since the Sixth Circuit Court of Appeals was the first court at the appellate level to explicitly allow a claim involving alleged discrimination against a younger protected class member in favor of older protected class members to go forward. The Cline decision does, however, seem to present a reasonable interpretation of the ADEA, but so does Hamilton. Although both relied heavily upon the language of the statute, they are diametrically opposed. Cline used the language of the statute to conclude that an "older" worker is someone forty or older. Hamilton, using the same language, determined that an "older" worker is someone who is relatively older than the person who benefited from the discrimination. Hamilton insisted limiting the protected class to forty and above precludes reverse discrimination suits; Cline contended that provision merely clarifies who is allowed to invoke the ADEA when faced with discrimination because of their age. The only difference in the method of analysis is that Hamilton allowed policy arguments and legislative history to affect its notion of what the statute says, whereas Cline claimed to limit its analysis to the words Congress actually chose to illustrate its intentions.

This subsection explores the strengths and weaknesses of the Cline opinion. It examines whether the language of the statute was as plain as the Cline court claimed, the significance of age provisions within the statute, and the relevance of Consolidated Coin. ${ }^{149}$

147. Id.

148. See infra Part I.B.

149. O’Connor v. Consol. Coin Caterers Corp., 517 U.S. 308, 312 (1996). 


\section{A. What Congress Said: The Plain Language Approach}

\section{An Introduction to the Plain Language Approach}

According to Cline, the only way to read the ADEA is to acknowledge that it allows reverse age discrimination claims. Yet this court is virtually the only court to read the ADEA in such a manner. If the language is so plain, why did every other court to decide the issue reach the opposite result? As one commentator points out, "[ $t]$ he plain language rule is invoked because of its rhetorical power; the Orwellian assumption, not entirely misplaced, that by saying something is true you make it true." ${ }^{150}$ Is this what the Sixth Circuit was doing in Cline? By flatly stating that holding otherwise would be to inject a policy position into the statute, are the judges in Cline really disguising their own policy views under the guise of plain language? Or does the statute, as written, call for all older workers over forty to be protected from age discrimination, whether or not they are younger or older than their counterparts?

Section 623(a)(1) of the ADEA states that it is unlawful for employers "to fail or refuse to hire or to discharge any individual or otherwise discriminate against any individual with respect to his compensation, terms, conditions, or privileges of employment, because of such individual's age."151 Section 631(a) limits the scope of the Act by confining the prohibitions in the Act to individuals who are "at least forty years of age."152 The majority read these two provisions together to hold that "by the law's plain language, an employer may not discriminate against any worker age 40 or older on the basis of age." 153

This interpretation of the statute is reasonable. Congress found age discrimination to be a problem. ${ }^{154}$ They chose, however, not to protect all Americans from age discrimination, but rather focused the statute to meet only the needs of those most commonly facing employment problems because of discriminatory assumptions about their age. ${ }^{155}$ Perhaps they wanted to protect these older workers from discrimination regardless of the age of the person the

150. Robert J. Gregory, Overcoming Text in an Age of Textualism: A Practitioner's Guide to Arguing Cases of Statutory Interpretation, 35 AKRON L. REV. 451, 466 (2002).

151. 29 U.S.C. § 623(a)(1) (2003).

152. See 29 U.S.C. $§ 631$ (a) (2003).

153. Cline v. General Dynamics Land Sys., Inc., 296 F.3d 466, 469 (6th Cir. 2002), cert. granted, 123 S. Ct. 1786 (2003)

154. See 29 U.S.C. $\S 621$ (2003).

155. See infra Part III.B. 
discrimination benefited. When Congress referred to "older workers" in the statute, it is possible they were referring to all workers older than forty, not just those workers who were discriminated against by virtue of the fact that they were older than the beneficiary of the discrimination.

The Cline opinion focuses the attention on the "plain language" of the statute and away from the intentions of the legislature and policy positions. The majority's statutory interpretation philosophy can be described as "new textualism," which "rests on the premise that "the constitutionally-mandated role of the Court is to interpret laws' [sic] using the actual statutory language, rather than to reconstruct legislators' intentions." ${ }^{156}$ All that matters is if the language in the statute is plain. The majority asserts, "courts must apply a statute as its language directs, not in accordance with judicial supposition as to what the legislature might better have written." ${ }^{157}$ Therefore, it is irrelevant if Congress wanted "older workers" to mean older than the beneficiary of the discrimination. Likewise, it is irrelevant if the situation of reverse discrimination did not even occur to Congress at all. It is also irrelevant if it violates fundamental notions of fairness by allowing a younger worker to sue under an age discrimination statute that just existed to benefit the oldest members of society. It is simply not the court's role to fix these problems; it is the court's role to apply the law as written.

In order to determine if language is plain, courts often look to canons of statutory construction. The Cline majority claimed they "rest[ed] their holding on familiar canons of statutory construction too elementary to require a citation." 158 Yet as Gregory points out, years ago Karl Llewellyn demonstrated a "fundamental truth about the process of statutory interpretation: that for every canon of construction leading to one result, there is a corresponding canon, of seemingly equal weight, leading to the opposite result." ${ }^{159}$

156. Gregory, supra note 150 , at 460 . For a critique of new textualism, see generally William N. Eskridge, Jr., The New Textualism, 37 UCLA L. REv. 621 (1990) (discussing the limits of new textualism as applied by Justice Scalia, such as its unreasonable stance on not using legislative history at all).

157. Cline, 296 F.3d at 469.

158. Id. at 467.

159. Gregory, supra note 150 , at 451. 


\section{Robinson v. Shell Oil Co.: Outlining the Plain Language Approach}

Without the aid of canons, the logical place to turn to for guidance is the approach used by the Supreme Court. ${ }^{160}$ In Robinson, a unanimous opinion, Justice Thomas announced the path the Supreme Court follows in interpreting a statute:

Our first step in interpreting a statute is to determine whether the language at issue has a plain and unambiguous meaning with regard to the particular dispute in the case. Our inquiry must cease if the statutory language is unambiguous and the statutory scheme is coherent and consistent. The plainness or ambiguity of statutory language is determined in reference to the language itself, the specific context in which that language is used, and the broader context of the statute as a whole. ${ }^{161}$

The question in Robinson was whether the word employee in $\S 704$ (a) in Title VII encompassed former employees as well as current employees. ${ }^{162}$ If it encompassed both, it would enable the petitioner to sue a former employer for post-employment retaliatory actions allegedly taken after he filed a charge with the EEOC. ${ }^{163}$ The Court believed "[a]t first blush" the term employees standing alone referred only to current employees, but believed this "initial impression" did not "withstand scrutiny in the context of $\S 704$ (a)." ${ }^{164}$ The context the Court used was the rest of statute. Without a temporal qualifier demonstrating whether former employees could sue in this provision of the statute, the Court searched for a temporal qualifier in other provisions of the statute. $^{165}$

After determining that no temporal qualifier existed, the Court then examined the definitional section. ${ }^{166}$ The statute defines employee as an individual employed by an employer, but this could mean, "is employed" or "was employed." 167 While the use of the term employee in some provisions necessarily includes more than just those employees who currently work for

160. This is not to say this is the only approach used by the Supreme Court. Depending on the alignment of the Justices, the Supreme Court has used other approaches, see William N. Eskridge, Jr. \& Philip P. Frickey, Statutory Interpretation as Practical Reasoning, 42 StAn. L. Rev. 321 (1990), but this case provides an outline of the way the Court deciphers a statute.

161. Robinson v. Shell Oil Co., 519 U.S. 337, 340-41 (1997).

162. Id. at 339 .

163. $I d$.

164. Id. at 341 .

165. Id.

166. Id. at 342 .

167. Id. 
the employer (such as provisions dealing with reinstatement), others use the term employee to unambiguously refer to a current employee (such as provisions dealing with salary or promotions). ${ }^{168}$ According to the Court, this only meant that the term "employee" had a plain meaning in certain sections, but did not have the same plain meaning throughout the statute. ${ }^{169}$ "Once it is established that the term 'employees' includes former employees in some sections, but not in others, the term standing alone is necessarily ambiguous and each section must be analyzed to determine whether the context gives the term a further meaning that would resolve the issue in dispute."170

Stating that the ambiguity behind the term "employees" must be resolved, the Court found that " $[t]$ he broader context provided by other sections of the statute provides considerable assistance in this regard." sections of the statute plainly contemplate that former employees will make use of Title VII's remedial mechanisms," it is most consistent to include former employees within the scope of $\S 704$ (a)'s protection, even though some sections clearly do not pertain to former employees. ${ }^{172}$ The Court was also persuaded by the argument of the petitioner and the EEOC that including former employees is consistent with the purpose of anti-retaliation provisions, because it does not allow employers to "retaliate with impunity against an entire class of acts under Title VII-for example, complaints regarding discriminatory termination." ${ }^{\prime 73}$ Including former employees ensures all employees will have "unfettered access to statutory remedial mechanisms." 174

Robinson seems to stand for the proposition that in order to determine whether statutory language is plain, one must examine the language in the context of the rest of the statute. Interpretation continues outward, examining the term at issue in the context of its provision and the other provisions in the statute. If the ambiguity cannot be determined from within the contours of the statute (using language, purpose, and logic as aids), only then can one resort to guides outside the statute, such as legislative history.

\footnotetext{
168. Id. at $342-43$.

169. Id. at 343 .

170. Id. at 343-44.

171. Id. at 345 .

172. Id.

173. Id. at 346 .

174. Id.
} 


\section{Using the Robinson Approach for the ADEA}

According to Robinson, the Court first determines whether the language at issue has a plain and unambiguous meaning with regard to the particular dispute in the case. The dispute in the case is whether under the ADEA, any individual aged forty or older is discriminated against because of his or her age when an employer treats older employees more favorably than the individual suing. Unlike Robinson, there is not one specific term within a provision at issue; the entire provision is problematic. Section 623(a)(1) of the ADEA states that it is unlawful for employers "to fail or refuse to hire or to discharge any individual or otherwise discriminate against any individual with respect to his compensation, terms, conditions, or privileges of employment, because of such individual's age."175

As in Robinson, the statutory language at issue first appears unambiguous. "Any individual" seems to include everyone. "Because of such individual's age" seems to mean that employers cannot consider age in employment decisions. However, this provision does not stand alone; it must be read in conjunction with $\S 631$ (a) where Congress expressly qualifies the term "any individual." ${ }^{176}$ Thus, the definitional section of the ADEA tells us that any individual does not mean everyone; it only means those individuals aged forty and over. ${ }^{177}$ Rephrasing $\S 623$ (a) to include $\S 631(\mathrm{a}), \S 623(\mathrm{a})$ now reads: it is unlawful for employers to fail or refuse to hire or to discharge any individual aged forty or over, or otherwise discriminate against any individual forty or over, with respect to his compensation, terms, conditions, or privileges of employment, because of such individual's age. ${ }^{178}$

Turning to the other provisions in the statute, we encounter the problem that all other courts have had: the term "older" in the Congressional Statement of Findings and Purpose. ${ }^{179}$ The word "older" occurs four times,

175. 29 U.S.C. § 623(a)(1) (2003).

176. See 29 U.S.C. $\$ 631$ (a) (2003).

177. See id.

178. See 29 U.S.C. $\S \S 623(a), 631$ (a) (2003).

179. 29 U.S.C. $\S 621$ (2003). The Congressional Statement of Findings and Purpose states: (a) The Congress hereby finds and declares that-(1) in the face of rising productivity and affluence, older workers find themselves disadvantaged in their efforts to retain employment, and especially to regain employment when displaced from jobs; (2) the setting of arbitrary age limits regardless of potential for job performance has become a common practice, and certain otherwise desirable practices may work to the disadvantage of older persons; (3) the incidence of unemployment, especially long-term unemployment with resultant deterioration of skill, morale, and 
referring to (1) "older workers" who are disadvantaged in finding employment, (2) arbitrary age limits that disadvantage "older persons," (3) incidence of unemployment "relative to the younger ages, high among older workers," and (4) the purpose of the Act to "promote employment of older persons based on their ability rather than age." "180 On one hand, the phrase older could mean workers aged forty and over. On the other hand, Congress could have meant older relative to another worker, and would not have used the term "older" (suggesting a comparison between the plaintiff and another individual) if it simply meant "old" (defined as workers aged forty and older). Thus, the term older workers is ambiguous and does not shed any light.

The next step is to turn to the greater context of the rest of the statute. One court has pointed out that there are sections in the ADEA that "come close to ensuring that younger workers may be discriminated against in favor of older workers." ${ }^{81}$ For example, $\S 623(\mathrm{f})(2)(\mathrm{A})$ allows employers to lawfully take any action which otherwise might be prohibited "to observe the terms of a bona fide seniority system that is not intended to evade the purposes of this chapter, except that no such seniority system shall require or permit the involuntary retirement of any individual . . . because of the age of such individual." 182 Since a seniority system usually benefits older workers because older workers are more likely to have longer years of service, if allowed, the individuals most likely to sue about treatment under a seniority system would be younger workers.

Consider, also, $\S 623(l)(1)(\mathrm{A})$, which states an employee pension benefit plan shall not be a violation of the statute solely because it "provides for the attainment of a minimum age as a condition of eligibility for normal or early retirement benefits." 183 As Judge Cole points out in his concurrence in Cline, "[i]f younger protected employees [would not otherwise be permitted to sue] their employers for the preferable pension treatment of older employees, then

\footnotetext{
employer acceptability is, relative to the younger ages, high among older workers; their numbers are great and growing; and their employment problems grave; (4) the existence in industries affecting commerce, of arbitrary discrimination in employment bec ause of age, burdens commerce and the free flow of goods in commerce. (b) It is therefore the purpose of this chapter [29 USCS $\S \S 621]$ to promote employment of older persons based on their ability rather than age; to prohibit arbitrary age discrimination in employment; to help employers and workers find ways of meeting problems arising from the impact of age on employment. 29 U.S.C. $\S \S 621$ (a)-(b) (2003) (emphasis added).

180. 29 U.S.C. $\S \S 621$ (a)-(b) (2003).

181. Conn v. First Union Bank of Va., No. 94-0901-R, 1995 U.S. Dist. LEXIS 9242, *4 n.3 (W.D. Va. Mar. 17, 1995).

182. 29 U.S.C. $\S 623(\mathrm{f})(2)(\mathrm{A})(2003)$.

183. 29 U.S.C. $\S 623(l)(1)(A)(2003)$.
} 
the minimumage exception in $\S 623(l)(1)$ (A) would not be necessary (because only younger employees could sue based on a minimum retirement age)."184

While the existence of these provisions could suggest that employees cannot sue under a reverse age discrimination theory, there are other situations in which a younger employee would be treated less favorably than an older employee. For example, there is no "carve-out" provision for a situation where an employer is paying greater compensation packages to fifty-year-old employees than the employer is paying to forty-five-year-old employees. ${ }^{185}$ Although employers are entitled to set a minimum age for attainment of other benefit plans such as pensions, nowhere in the statute does such an exemption exist for the retirement health benefit plan at issue in Cline. ${ }^{186}$ Without foreclosing all avenues for "younger older" employees to complain of reverse age discrimination, or without stating expressly that the ADEA does not encompass reverse age discrimination, the only way to give both provisions meaning is to allow "younger older" employees to sue under the ADEA based on more favorable treatment to older workers. Like the provisions in Robinson that did not include former employees, some sections clearly do not encompass "younger older" workers. Also, as with the provisions in Robinson that did include former employees, there are provisions in the ADEA that could include "younger older" employees. Since the ADEA does not include "younger older" workers in certain sections, it is more "consistent" to read the ADEA as including "younger older" workers in the sections that do not expressly exempt them.

Supporting this view, Judge Cole observed that allowing younger protected class members to sue for all discrimination based on age furthers the purposes of the ADEA. ${ }^{187}$ In Robinson, the Court believed including former employees supported the anti-retaliation provision's purpose. "[These]

184. Cline v. Gen. Dynamics Land Sys., Inc., 296 F.3d 466, 473 (6th Cir. 2002), cert. granted, 123 S. Ct. 1786 (2003).

185. See Recent Case, supra note 4, at 1538.

186. The Harvard Law Review's Recent Case commentary implies that the health benefit plan in Cline falls under $\S 623(l)(1)(\mathrm{A})$ 's exception for pension plans. Id. at 1537-38. The provision in the collective bargaining agreement, however, was not part of a pension plan but instead a welfare benefit plan, which $\S 623(l)(1)(A)$ does not include. See Cline v. Gen. Dynamics Land Sys., Inc., 98 F. Supp. 2d 846, 847 (N.D. Ohio 2000), rev'd, 296 F.3d 466 (6th Cir. 2002), cert. granted, 123 S. Ct. 1786 (2003). Section 623(l)(1)(A) uses ERISA's definition of employee pension benefit plan. ERISA clearly defines pension plans and welfare benefit plans separately. See 29 U.S.C. §§ 1002(1)-(2) (2003).

187. Cline, 296 F.3d at 474. 
arguments carry persuasive force given their coherence and their consistency with a primary purpose of antiretaliation provisions . . .".188

Whether a forty-two-year-old loses her job or benefits to a fifty-two-yearold or a thirty-two-year-old, if the employer bases the termination of the employee's job or benefits on his or her age, it is not based on his or her ability. Congress found that older workers are disadvantaged in retaining and regaining employment because generally, the older a worker is, the more experience he or she has, and the higher his or her wages. ${ }^{189}$ If a worker who is younger than some protected class members, yet older than most of the workforce, loses his or her job because of age discrimination, according to congressional findings, he or she will still have the same problem of making too much and being overqualified.

Secondly, if an employer arbitrarily picks the age of sixty to start giving preferential treatment, a fifty-year-old is in the same position as a sixty-yearold would be if the employer arbitrarily picks the age of sixty to start giving negative treatment. ${ }^{190}$ Finally, Congress has already isolated the group of workers aged forty and over because of the special problems individuals in this group face because of their age. ${ }^{191}$ According to the congressional findings, the problems of unemployment, the burdens on commerce, and the deterioration of skills and morale exist for a forty-year-old, fifty-year-old, or sixty-year-old whose job is terminated or whose benefits are reduced, whether the termination or reduction in benefits are in favor of younger workers or older workers. ${ }^{192}$ Hence, allowing younger workers to sue their employers when their employers treat older workers better is in accord with the primary purposes of the ADEA, as stated by Congress. ${ }^{193}$

In addition, as in Robinson, the majority's reading corresponds with the EEOC's approach. Title 29 C.F.R. § 1625.2(a) reads:

188. Robinson v. Shell Oil Co., 519 U.S. 337, 346 (1997).

189. 29 U.S.C. $\S 621(\mathrm{a})(1)(2003)$.

190. 29 U.S.C. $\$ 621(\mathrm{a})(2)(2003)$

191. 29 U.S.C. $\S 621(\mathrm{a})(3)(2003)$.

192. 29 U.S.C. $\S \S 621(a)(3)-(4)(2003)$.

193. One could argue that in Robinson, including former employees substantially furthers the statute's purpose, whereas not including them actually hinders Title VII's purpose because it allows employers to retaliate against their former employees without consequence. Under this view, it is relatively uncontroversial to include former employees. In this situation, however, allowing younger members of the protected class to sue may result in employers no longer giving preferential treatment to older workers. Some may argue this was not the intent of the ADEA. Nevertheless, for the purposes of this section, if one believes a court's role is to only follow the direction Congress has given it in a statute, allowing younger protected class members to sue furthers the purposes stated in the Congressional Statement of Findings and Purpose. For congressional intent and policy, see infra Part III.B and III.C. 
It is unlawful in situations where this Act applies, for an employer to discriminate in hiring or in any other way by giving preference because of age between individuals 40 and over. Thus, if two people apply for the same position, and one is 42 and the other 52 , the employer may not lawfully turn down either one on the basis of age, but must make such decision on the basis of some other factor. ${ }^{194}$

Although Hamilton argued that courts only cite this regulation for the proposition that it is still age discrimination if an employer discriminates against an older individual in favor of a younger individual in the protected class ${ }^{195}$ the regulation is clearly broader than this. It states that the employer may not take age into consideration for either the forty-two or fifty-two-yearold who has applied for the same position, not just for the fifty-two-year-old. Courts that have alleged that this regulation oversteps the EEOC's boundaries ${ }^{196}$ have concluded this without much analysis regarding the deference due to the agency. Of course, the Cline court also did not analyze its decision to give the regulation deference. It suffices for the purposes of this Note to point out that while this is only an interpretive regulation that is not definitive on the issue, the EEOC's position shows that the Cline court's interpretation of the statute is not wholly unsupported. ${ }^{197}$

\section{The Significance of Consolidated Coin and the Forty Plus Age Requirement}

Finally, the strength of analysis in Cline depends on the level of support provided by Supreme Court precedent and $\S$ 631(a), which limits the protected class to forty and older. For the most part, the Supreme Court's decision in O'Connor v. Consolidated Coin Caterers Corp. supports Cline's view of the statute. In Consolidated Coin, a fifty-six-year-old plaintiff sued his employer when his employer replaced him with a forty-year-old. ${ }^{198}$ The question before the Court was "whether a plaintiff alleging that he was discharged in violation

194. 29 C.F.R. § 1625.2(a) (2003) (emphasis added).

195. Hamilton v. Caterpillar Inc., 966 F.2d 1226, 1228 (7th Cir. 1992).

196. See id. at 1228; Conn v. First Union Bank of Va. No. 94-0901-R, 1995 U.S. Dist. LEXIS 9242 , at *6-7 (W.D. Va. Mar. 17, 1995).

197. For a discussion of the deference courts give EEOC regulations overall, see generally Theodore W. Wern, Note, Judicial Deference to EEOC Interpretations of the Civil Rights Act, the ADA, and the ADEA: Is the EEOC a Second Class Agency?, 60 Оніо ST. L.J. 1533 (1999) (noting that while courts have deferred to the EEOC's position under the ADEA more than they have under Title VII, overall courts do not give the EEOC as much deference as they give other agencies).

198. O’Connor v. Consol. Coin Caterers Corp., 517 U.S. 308, 309 (1996). 
of the [ADEA] must show that he was replaced by someone outside the age group protected by the ADEA" to establish a prima facie case. ${ }^{199}$ The Court held that a plaintiff did not have to show that his or her replacement was outside the protected class. ${ }^{200}$ The Court also stated, however, that in order to create an inference of illegal discrimination, a plaintiff must show that his or her replacement is "substantially younger," because this requirement is more probative in ferreting out illegal age discrimination than requiring the replacement to be outside the protected class. ${ }^{201}$

As Judge Cole noted in his concurrence in Cline, the impact of this decision is the suggestion "that reverse age discrimination claims are not permitted under the ADEA because when discriminated against in favor of older workers, younger protected workers cannot prove that substantially younger persons were favored." ${ }^{202}$ Judge Cole dismissed this concern by stating that the Cline decision does not violate Supreme Court precedent because (1) the Supreme Court was not faced with a reverse discrimination claim; (2) the holding acknowledged that a plaintiff can sue his or her employer despite being replaced by a fellow member of his or her protected class; ${ }^{203}$ and (3) the Cline court based its holding upon the same plain language as the Court did in Consolidated Coin. ${ }^{204}$ He optimistically stated his belief that the Supreme Court would change its holding in Consolidated Coin from a "substantially younger" requirement to a "substantial difference in age" requirement if faced with a reverse discrimination claim. ${ }^{205}$

Even if Judge Cole's arguments have validity, it is undeniable that the language in Consolidated Coin is damaging to the holding in Cline. Nonetheless, the Supreme Court's rationale supports claims of reverse age discrimination. Pointing to $\S 623(a)(1)$ and $\S$ 631(a), Justice O'Connor notes that:

199. Id.

200. Id. at 313 .

201. See id.

202. Cline v. Gen. Dynamics Land Sys., Inc., 296 F.3d 466, 475 (6th Cir. 2002) (Cole, J., concurring), cert. granted, 123 S. Ct. 1786 (2003). While Cline is a direct evidence case, Judge Cole feared that the Supreme Court's dictates for establishment of a prima facie case may still reflect their opinion on reverse age discrimination cases in general. See id.

203. Judge Cole's opinion actually states that "members within the protected class may sue one another." Id. Of course, the members would not sue each other, but a member would sue his or her employer after the employer replaced him or her with another class member.

204. $I d$.

205. $I d$. 
This language does not ban discrimination against employees because they are aged 40 or older; it bans discrimination against employees because of their age, but limits the protected class to those who are 40 or older. The fact that one person in the protected class has lost out to another person in the protected class is thus irrelevant, so long as he has lost out because of his age..$^{206}$

The court in Cline based its holding on the same reasoning. "[B]y the law's plain language, an employer may not discriminate against any worker age 40 or older on the basis of age." 207 By reasoning that "Congress has singled out the over-40 class of workers from the general workforce for protection from age discrimination by their employers, ${ }^{, 208}$ the Cline court has followed the Supreme Court's mandate that a worker aged forty and over cannot be discriminated against "because of his age."209 Because of the similar rationales, whether the "substantially younger" requirement applies to direct evidence reverse discrimination claims is unclear.

Furthermore, on a related note, though Congress has chosen in $\S 631$ (a) to limit the protected class to the oldest portion of the workforce, it still does not show whether they intended the ADEA to encompass reverse age discrimination. Courts have argued that limiting the plaintiff class to forty and older indicates that Congress was worried about discrimination against an individual who is older than the beneficiary. ${ }^{210}$ Hamilton argued that if Congress had limited the protected classes under Title VII to women and African-Americans, there would be no authority for reverse discrimination suits. ${ }^{211}$ However, age is different from race and sex. Unlike race, which can be carved into different categories (such as African-American, Caucasian, or Asian), it is not possible to permanently categorize age as young and old. An African-American is still an African-American when compared to a person of another race, whereas an "old" person is not always "old" when compared to a person of a different age.

Congress could have allowed any individual to sue because of arbitrary age discrimination. Take, for example, a case where an employer acts on a stereotypical assumption that an eighteen-year-old is too immature for a job. Congress chose, however, to limit the potential plaintiffs to the portion of the workforce that experiences the most harm when they are victims of age

206. O'Connor v. Consol. Coin Caterers Corp., 517 U.S. 308, 312 (1996).

207. Cline, 296 F.3d at 469.

208. Id. at 471 .

209. Consol. Coin, 517 U.S. at 312.

210. See id.; Conn v. First Union Bank of Va., No. 94-0901-R, 1995 U.S. Dist. LEXIS 9242, at*3 (W.D. Va. Mar. 17, 1995).

211. Id. 
discrimination. ${ }^{212}$ Therefore, it is reasonable to assume, based on the plain language of the statute and the non-specific references regarding older workers in the Statement of Findings and Purpose, that Congress placed a limitation on the protected class not because they were concerned about the "relatively older" worker, but because they were concerned about the problems of age discrimination among workers aged forty and over in general.

Thus, if one employs the new textualist approach to deciphering the ADEA as detailed by the Supreme Court in Robinson, it is coherent to determine that the plain text of $\S 623(\mathrm{a})$, in context of the entire statute, includes discrimination against younger protected class members in favor of older protected class members in its prohibition against age discrimination. This is the approach taken by the Sixth Circuit in Cline, and it appears to be consistent with what Congress indicated in the statute.

Although the new textualist approach discourages the use of legislative history, a statute does not exist in a vacuum. It is unclear whether the judges in Cline intended to use new textualist approach to avoid dealing with the legislative history, but that is the practical effect of the opinion. Therefore, the next section will explore the original intention of Congress to determine whether the "plain language" approach is consistent with the "legislative history" approach.

\section{B. What Congress Meant to Say: A Legislative History Approach}

\section{The Original Idea}

In the late 1960's, the problem of unemployment fell disproportionately on older workers. University of Texas Law Professor Samuel Issacharoff described the problem as an “"Elders Need Not Apply' attitude."213 "In 1967, half of all private job openings were barred to applicants over fifty-five, and a quarter to those over forty-five." 214 Congress first broached the subject of age discrimination in employment during the passage of the Civil Rights Act of 1964, which included Title VII's prohibitions against race, sex, color, and religious discrimination. ${ }^{215}$ Although it did not include age discrimination in

212. See 29 U.S.C. $\S$ 621(a)-(b) (2003).

213. Samuel Issacharoff \& Erica Worth Harris, Is Age Discrimination Really Age Discrimination?: The ADEA's Unnatural Solution, 72 N.Y.U. L. REv. 780, 783 (1997).

214. Id.

215. See Bryan B. Woodruff, Note, Unprotected Until Forty: The Limited Scope of the Age Discrimination in Employment Act of 1967, 73 IND. L.J. 1295, 1296 (1998). 
its prohibitions, it directed the Secretary of Labor to study the plight of the older worker. ${ }^{216}$

The Secretary of Labor produced a study known as the Wirtz Report, which provided the impetus for passing the ADEA. ${ }^{217}$ The Secretary's report stated individuals aged forty-five and older usually faced discrimination as a result of assumptions about the effect of age on the ability to perform a job when there is in fact no basis for the assumptions. ${ }^{218}$ The lost productivity and increased unemployment benefits in turn placed a substantial burden on the economy and had an adverse psychological effect on older workers. ${ }^{219}$

The goals that the Report identified for age discrimination legislation, the reduction of wasted human resources in the involuntary unemployment and underemployment of older American workers and the enhancement of human dignity for older Americans, were reflected in Congressional statements in support of the Act and in the Act's statement of finding and purpose. ${ }^{220}$

As a result of the problems identified in the Wirtz Report, Congress passed the ADEA "after little debate and even less public attention."221

From its inception, however, Congress understood age discrimination to be a form of discrimination distinct from other traditional forms such as race or sex discrimination. ${ }^{222}$ Age discrimination is more complex, since it is based on many interrelated factors. Unlike other forms of discrimination, it seldom involves animus towards a worker because of age. ${ }^{223}$ The Wirtz Report indicates that " $[t]$ he 'discrimination' older workers have most to fear ... is not from any employer malice, or unthinking majority, but from the ruthless play of wholly impersonal forces - most of them part of what is properly, if sometimes too casually, called 'progress.'",224

The most common problem is "the setting of specific age limits beyond which employers will not consider workers for a vacant job, regardless of

216. See 42 U.S.C. § 2000e-14 (2000).

217. Michael C. Harper, ADEA Doctrinal Impediments to the Fulfillment of the Wirtz Report Agenda, 31 U. Rich. L. ReV. 757, 757 (1997).

218. See W. Willard Wirtz, The Older American Worker: Age Discrimination in Employment, Report of the Secretary of Labor to the Congress Under Section 715 of the CiviL Rights ACT OF 1964, 2 (U.S. Printing Office 1965).

219. See id. at 18-19.

220. Harper, supra note 217, at 762 .

221. Issacharoff \& Harris, supra note 213, at 785.

222. Id. at 785-86.

223. See WirTz, supra note 218 , at 2.

224. Id. at 3 . 
ability."225 Boston University School of Law Professor Michael Harper describes this as "“statistical discrimination,' the rejection of all members of a status group because of certain characteristics of a large proportion of the group relative to those outside the group." ${ }^{226}$ Statistical discrimination might be economically rational for an employer at the hiring stage in particular for three reasons. $^{227}$ First, assessing individual applicants is expensive. ${ }^{228}$ Second, many employers are concerned about the limited future work expectancy and training costs. ${ }^{229}$ It may be easier to exclude all older workers, even though some workers may have stayed longer than younger workers if given the chance. ${ }^{230}$ Third, given that employers are concerned about higher wage expectations of older employees, they may believe the average older worker would impose higher costs than would a younger worker of equal productivity. ${ }^{231}$

The Wirtz report also identified "the force of certain circumstances which unquestionably affect older workers more strongly, as a group, than they do younger workers. ${ }^{232}$ For example, displaced older workers have more difficulty finding new employment because the older worker has to compete with younger, better educated workers who may be more familiar with new technology. ${ }^{233}$ The report also recognized that various personnel programs and practices designed to bring "efficiency, equity, order, and improved fringe benefits" may actually work to the detriment of older workers. ${ }^{234}$ For instance, an employer concerned about the rising costs of a health plan or private pension plan with the addition of older workers may be reluctant to hire someone in an older age bracket. ${ }^{235}$ Overall, the report recommended not only removing age limits to hiring, but also adjusting institutional arrangements that indirectly restrict the employment of older workers. ${ }^{236}$

225. Id. at 6 .

226. Harper, supra note 217 , at 759.

227. $I d$.

228. $I d$.

229. Id.

230. $I d$.

231. Id.

232. WIRTZ, supra note 218 , at 11 .

233. Id. at 11-15.

234. See id. at 15-17.

235. Id. at 16

236. Id. at 21 . 


\section{Did Congress Intend to Include Reverse Age Discrimination?}

The legislative history of the ADEA indicates Congress passed the antidiscrimination legislation out of concern for the plight of workers aged forty and older. It appears Congress believed the older segment of the workforce felt the effects of age discrimination most severely. Since these problems would occur whether the beneficiary of the discrimination was the usual beneficiary (i.e., a person below forty) or the usual victim (i.e., a person towards the upper end of the protected age group), these considerations support the recognition of reverse age discrimination.

However, the focus of the Wirtz Report was on the problem of employers who would not consider persons beyond a certain arbitrary age for employment. The Act's primary sponsor, Senator Jacob K. Javits (R-N.Y.), stressed the narrow scope of the ADEA, emphasizing that Congress designed the statute to counter the "widespread irrational belief that once men and women are past a certain age they are no longer capable of performing even some of the most routine jobs." ${ }^{237}$ Thus, a major impetus for passing the ADEA was to combat the stereotypical thinking that fueled the "Elders Need Not Apply' Attitude." 238 Under this facet of the ADEA, reverse age discrimination does not play a role. While individuals over forty surely encountered employers who refused to hire them because of age, it is more probable that the arbitrary age limits often kept out the older end of the age group. This is supported by commentary accompanying the research materials in the Wirtz Report: "At forty, [a worker] might find age restrictions becoming more common, as employers begin to reveal a pattern of preference for younger workers. By age 45 , his employment opportunities are likely to contract sharply. They shrink more severely at age 55 and virtually vanish by age 65. ${ }^{239}$

Therefore, Congress probably envisioned an employer who chose to hire a forty-two-year-old over a fifty-two-year-old, believing the younger employee to be more productive. Although still based on stereotype about age, Congress probably was not considering an employer who would choose the fifty-two-

237. Clint Bolick, The Age Discrimination in Employment Act: Equal Opportunity or Reverse Discrimination?, Policy ANAL Ysis No. 82 Feb. 10, 1987, at http://www.cato.org/pubs/pas/pa082.html(last visited Nov. 15, 2003).

238. See Issacharoff \& Harris, supra note 213 , at 783-84.

239. WIRTZ, supra note 218 , at 3. 
year-old, believing the older employee to be more mature. The next section asks whether it is sound policy to allow reverse age discrimination claims.

\section{What Congress Should Have Said: Policy Implications of Reverse Age Discrimination}

\section{Who is an Older Worker, Anyway?}

The Wirtz Report did not recommend an explicit age limit, but focused the report on the plight of individuals aged forty-five and older. ${ }^{240}$ The Senate and House committees decreased the lower age limit to forty, because they believed that is when age discrimination becomes most prevalent and because many states with age discrimination legislation set the age limit at forty. ${ }^{241}$ The committees considered an even lower age limit resulting from testimony about age discrimination by airlines against stewardesses starting at age thirtytwo. ${ }^{242}$ Nevertheless, they started the age protections at age forty because they "felt a further lowering of the age limit proscribed by the bill would lessen the primary objective; that is, the promotion of employment opportunities for older workers." 243

Congress amended the ADEA in 1978 to raise the upper age limit from sixty-five to seventy. ${ }^{244}$ It then amended the ADEA to state that mandatory retirement before age seventy is prohibited; it was a compromise between those who wanted to eliminate mandatory retirement entirely and those who wanted to retain mandatory retirement for economic reasons. ${ }^{245}$ By 1986, the public supported the elimination of mandatory retirement. ${ }^{246}$ Congress completely removed the upper age limit and eliminated mandatory retirement. ${ }^{247}$ During discussion of the Amendment, Representative Claude Pepper stated: "Age discrimination is as detestable and unjust as racial, religious, or sex discrimination. Our society, which prides itself on a system that guarantees equality of opportunity and freedom of choice for all of its people, for too long has tolerated the mean and arbitrary indignity of [age

240. See id. at 2, 5-7, 18; Woodruff, supra note 215, at 1297.

241. Woodruff, supra note 215, at 1297.

242. Id. at 1297-98.

243. Id. at 1298 .

244. House Comm. On Educ. and Labor, Age Discrimination in Employment Act of 1967, H.R. REP. No. 90-805, at 6 (1967), reprinted in 1967 U.S.C.C.A.N. 2213, 2219.

245. Woodruff, supra note 215, at 1299.

246. Id. at 1300 .

247. $I d$. 
discrimination.]"248 Representative Pepper is not the only one to describe age discrimination in broad terms. Except for the setting of an age limit, the ADEA refers to older persons generally and age discrimination broadly.

One argument in favor of recognizing reverse age discrimination is the age limit itself. For all the times Congress has tinkered with the age limitations, it has never raised the age limit to eliminate the "younger older workers" in their early forties. This is even despite the graying of America since the time when Congress passed the ADEA. In 1967, 36.3\% of the population was forty and over, compared to the population in 1994, where the forty and over group made up $48.4 \%$ of the population. ${ }^{249}$ Americans are living longer and retiring later, but Congress believes the younger older worker is still in need of special protection. This is even true assuming the older one becomes, the more benefits he or she needs and the more vulnerable he or she becomes. Yet by keeping the focus on workers aged forty and over, Congress is recognizing that the problems identified in the Statement of Findings and Purpose is especially severe amongst all workers aged forty and over. If one has lost benefits or a job because of age, it does not matter whether the individual lost out to a person half his or her age or someone older; he or she will still be affected enough to warrant special protection.

This is true, unless, of course, the ADEA is not an individual remedy. If Congress enacted the ADEA to eradicate age discrimination for the greater good of the protected age group, courts should not recognize reverse discrimination claims. Assume the problems grow more severe the older one becomes. Since the beneficiary of reverse age discrimination is an individual who is more likely to experience greater problems if unemployed or with less benefits, as a policy matter, courts should not recognize the plaintiff's claim. If the ADEA is an individual remedy, however, it should not matter who the beneficiary is. If an individual aged forty or older is discriminated against within the coverage of the Act on the basis of his or her age, he or she should be entitled to recovery, period. Although Congress may have enacted the ADEA because of the problems of the forty and older group as a whole, ${ }^{250}$ it phrased the ADEA in individual terms. ${ }^{251}$

Because Consolidated Coin allowed an "older older" class member to sue his employer when discriminated in favor of "younger older" member who was still part of the protected class, it supports this view as well. "With the

250. See 29 U.S.C. $\S 621$ (2003) (referring to the problems of "older workers"). 251. See 29 U.S.C. $§ 623(a)(1)$ (2003) (stating the right of "any individual" to sue). 
O'Connor ruling, the Supreme Court emphasized that the important protection offered by the ADEA was given to individuals who were discriminated against because of their age individually, not to a particular age group (i.e., those over forty.)" 252 Indeed, this notion is reflected in the language: "The fact that one person in the protected class has lost out to another person in the protected class is thus irrelevant, so long as he lost out because of his age."253

However, even if the ADEA is an individual remedy, which recognizes that all workers over forty face special problems in the workforce, one cannot deny that age is a continuum. In fact, it is unlikely larger society would consider all individuals over forty as belonging to the same group.

[T]o analyze "the elderly" as a group in terms of all individuals over forty years old is overly simplistic. As individuals grow older, they undoubtedly do become more discrete and insular. At some point, popular prejudice might lead employers to conclude one "is too old" for the job market or a particular job, and society undoubtedly begins to exclude older individuals to such an extent that they begin to resemble other discrete and insular groups. $^{254}$

There is a tension between reverse age discrimination and characterizing a forty-year-old as "old." Perhaps compared to a twenty-four-year-old fresh out of college, trained with up-to-date technology, a forty-year-old may qualify as "old." However, if one compares a forty-year-old to the fellow members of his or her protected class, a forty-year-old may actually appear to be "young." A forty-year-old may only be in mid-career, while someone in his or her late fifties or early sixties may be nearing his or her career's end, and those in their seventies usually do not work at all. Courts have observed that the beneficiaries of age discrimination are likely to be "younger older" workers closer to forty, at least in jobs requiring experience. "If no intra-age group protection were provided by the ADEA, it would be of virtually no use to persons at the upper ages of the protected class whose jobs require experience since even an employer with clear anti-age animus would rarely replace them with someone under 40." 255

252. Kurt Schaub, Note, The "Substantially Younger" Requirement in O'Connor v. Consolidated Coin Caterers Corp.: Will ADEA Plaintiffs Lose Again?, 16 HofstRa LAB. \& EMP. L.J. 225, 237 (1998). 253. See O'Connor v. Consol. Coin Caterers Corp., 517 U.S. 308, 312 (1996).

254. Michael J. Van Sistine \& Bruce Meredith, The Legality of Early Retirement Incentive Plans: Can Quantum Physics Help Resolve the Current Uncertainty?, 84 MARQ. L. Rev. 587, 604 (2001).

255. Maxfield v. Sinclair Int'1, 766 F.2d 788, 792 (3d Cir. 1985). See also McCorstin v. U.S. Steel Corp., 621 F.2d 749, 754 (5th Cir. 1980) (noting that employers tend to replace protected workers with a younger worker in the protected class, especially in management and technical fields where experience is a necessary prerequisite). 
Therefore, under this view, it is irrational to allow the ADEA to encompass reverse age discrimination claims. As noted earlier, America has "grayed" since the late 1960's and will continue to do so as the youngest members of the "baby boomers" move into the ADEA's protected class. ${ }^{256}$ As "medical innovation" increases not only the expected life span of Americans, but also the average "health span" (i.e., the "number of years that people remain in good health"), the median age for American workers grows higher. ${ }^{257}$ What was "old" in 1967 may no longer be "old" in 2003. Although the upper age limit of the protected class has been changed multiple times, the lower end has remained the same. ${ }^{258}$ Perhaps the time has come for Congress to re-evaluate what an "older" worker is. Unless studies demonstrate that all workers ages forty and over still experience the brunt of age discrimination, claims of reverse age discrimination and arbitrarily dividing the line at age forty do not make sense from a policy standpoint.

\section{The Transformation of the ADEA}

In 1967, Congress had a clear image of whom it sought to protect. The ADEA was for a common man, not old, but older, with gray at his temples and a few lines on his face, with years of experience in his field, who, upon reading the classifieds, found several jobs for which he was qualified but for which applications from those over forty were not accepted. ${ }^{259}$

The modern day ADEA plaintiff is much different, however. "Rather than challenging barriers to job seeking, the typical litigant is concerned about holding onto a job he or she already has." ${ }^{260}$ By the mid-1980's, 76\% of ADEA cases involved termination claims, as compared to only $9 \%$ of the cases involving refusal to hire claims. ${ }^{261}$ Failure to promote claims made up $6.6 \%$ of the cases, demotion made up $6.3 \%$, and compensation and benefits made up the remaining 1.9\%. ${ }^{262}$ Accordingly, "[t]he numbers are in complete conflict with what had been predicted by the original legislators and are inconsistent with the original intent of the ADEA. ${ }^{263}$

256. See Schaub, supra note 252, at 227.

257. $I d$.

258. See Woodruff, supra note 215 , at 1295.

259. Issacharoff \& Harris, supra note 213, at 793.

260. Id.

261. Id.

262. Id.

263. Id. 
Professor Issacharoff and Erica Worth Harris believe there is a simple explanation as to why the ADEA has developed in this manner. ${ }^{264}$ They describe the life-cycle model of employment as one where an employee is paid less than his or her marginal productivity during the middle stages of his or her career. ${ }^{265}$ To ensure an increasing wage structure, employers pay workers more than their worth during the beginning and ending phases of their careers. ${ }^{266}$ Although there are benefits to this arrangement for both the employer and employee, the employee risks the possibility that "an employer under financial stress may come to see an expensive senior employee as an unaffordable luxury, regardless of implicit contractual obligations." ${ }^{267}$ Then, new employers are reluctant to hire the employee, because they are unwilling to assume "a wage premium for services delivered to another employer," not to mention the cost of firm-specific training for an employee whose career is almost over. ${ }^{268}$

Although this transformation into a statute with a wrongful discharge emphasis is not unique to the ADEA, it is different from Title VII partly because of the type of plaintiff it favors. ${ }^{269}$ "A fired fifty-five-year-old white male manager who worked at his job slightly over fifteen years brings the average ADEA claim."270 Professor Issachroff and Erica Worth Harris propose:

This profile of both the typical ADEA plaintiff and the subject of litigation suggests that the ADEA has developed into a wrongful termination cause of action for employees entering the final stage of employment rather than the protection against categorical action based on the sort of invidious motivation generally associated with the term "discrimination" and originally envisioned by Congress. ${ }^{271}$

The other interesting change with the ADEA is the extent it protects benefits for older workers. One commentator goes so far to argue that special interest groups have perverted the ADEA into a statute that "mandate[s] . . . preferential treatment for workers over forty." 272 Professor Issachroff and Erica Worth Harris point to the substantial influence the American

264. Id.

265. Id. at 789 .

266. Id.

267. Id. at 791 .

268. Id. at 792 .

269. Id. at 797.

270. Woodruff, supra note 215 , at 1300.

271. Issacharoff \& Harris, supra note 213, at 796.

272. Bolick, supra note 237. 
Association of Retired Persons ("AARP") has had on the development of the ADEA. ${ }^{273}$ For example, although the AARP initially opposed targeted Early Retirement Incentive Plans ("ERIPs"), which offered an incentive for workers under a certain age to retire early, the AARP switched gears to avoid elimination of ERIPs entirely. ${ }^{274}$ Their position found support in Congress; the ADEA now allows targeted ERIPs as long as employers offer them to everyone over a certain minimum age. ${ }^{275}$ "The ADEA now codifies an express double standard: classifications based on age are presumptively discriminatory, unless they benefit older workers."276

Yet individuals ages forty and over are not what most people picture as typical victims of discrimination.

Far from being discrete and insular, the elderly represent the normal unfolding of life's processes for all persons. As a group, older Americans do not suffer from poverty or face the disabling social stigmas characteristically borne by black Americans at the start of the civil rights era. Indeed, [there is] extensive evidence that older Americans are a relatively privileged social group sharing none of the characteristics of groups to which society may owe an ongoing obligation of remediation. ${ }^{277}$

This is one reason why the Hamilton court compares age discrimination with disability discrimination, stating simply, "[t]he young, like the nonhandicapped, cannot argue that they are similarly victimized." ${ }^{278}$ The concurrence in Cline admits that the court's holding is "counterintuitive."279 It is fair to say that the problems of the protected class increase the older one becomes. It is also fair to say that "the elderly" become more discrete and insular as they age. ${ }^{280}$ It is ironic that a statute enacted to help combat these problems can now work to the detriment of these workers.

273. Issacharoff \& Harris, supra note 213 , at 811.

274. Id. at $815-16$.

275. Id. at 816 .

276. Id. at 819 .

277. Id. at 781 .

In fact, given the role of de jure racial and gender discrimination in this country in shaping the workforce into the mid-sixties, and the continuing effects of de facto discrimination, the majority of individuals who qualify for most ERIPs will be white, male, and at least middle class - perhaps one of the most powerful groups in our society.

Van Sistine \& Meredith, supra note 254, at 604; see also Woodruff, supra note 215, at 1307 (stating that older workers have considerable political power; almost one in five voters is a member of the AARP).

278. Hamilton v. Caterpillar Inc., 966 F.2d 1226, 1228 (7th Cir. 1992).

279. Cline v. Gen. Dynamics Land Sys., Inc., 296 F.3d 466, 476 (6th Cir. 2002) (Cole, J., concurring), cert. granted, 123 S. Ct. 1786 (2003).

280. See Van Sistine \& Meredith, supra note 254, at 604. 
Moreover, recognizing reverse age discrimination would limit the freedom of employers to offer any sort of benefit to the oldest workers, whether it is to encourage them to retire or to reward them for years of service. For example, the dissent in Cline worries about the effect on collective bargaining agreements, believing that the holding will interfere with the otherwise voluntary negotiations between unions and employers. ${ }^{281}$ Regardless of whether one believes that economics should be a factor under the ADEA, ${ }^{282}$ if the choice in Cline was between only offering full health benefits to those fifty or older or giving full benefits across the board but laying off many workers, one may not find the reverse age discrimination claim to be as objectionable. ${ }^{283}$

Looking at the various reverse age discrimination claims brought since the ADEA's passage, a common pattern emerges. ${ }^{284}$ First, not a single case was brought as a result of a failure to hire. In fact, not a single case involved a termination of a "younger older person" in favor of an "older older" person. All of the cases involved the denial of benefits in some form. For the reasons noted above, perhaps the best policy is not to recognize claims for reverse age discrimination.

\section{A New Approach for Reverse Age Discrimination Claims}

While the plain language of the ADEA supports reverse age discrimination claims, including the Congressional Statement of Purpose, there is serious doubt whether Congress ever intended (or even considered)

281. Cline, 296 F.3d at 476 (Williams, J., dissenting).

282. For arguments that economically based decisions should not be tolerated under the ADEA, see Judith D. Fischer, Public Policy and the Tyranny of the Bottom Line in the Termination of Older Workers, 53 S.C. L. REv. 211 (2002) (arguing that salary-based terminations defeat the purposes of the ADEA); Harper, supra note 217 (stating that current doctrine's inclusion of salary-based defenses, among other reasons, have impeded the success of meeting the Wirtz Report's fundamental goals of reducing the unemployment, underemployment, and loss of dignity of older workers). For arguments that economic reasons to discriminate should be valid under the ADEA, see generally Van Sistine \& Meredith, supra note 254 (suggesting a new framework to analyze voluntary early retirement incentive plans in order to take into account reasonable considerations such as financial savings); Issacharoff \& Harris, supra note 213 (arguing that anti-discrimination statutes are not the best way to deal with the economic vulnerability of older workers and suggesting an approach to address the competing concerns of loss of dignity and opportunistic political capture of special treatment); Bolick, supra note 237 (contending that the ADEA now mandates special treatment to older workers instead of according age a neutral status).

283. See Harper, supra note 217 , at 778-79 (stating that society rationally may want certain types of age discrimination to continue as long as it is economically efficient, weeds out unproductive workers and does not consist of a blanket policy against the employment of all older workers).

284. See cases discussed infra Part 1. 
reverse age discrimination claims. There are policy and legal arguments for recognizing reverse discrimination claims. However, given the legislative intent of Congress, and given that problems increase the older one becomes, there are serious policy problems with allowing reverse age discrimination claims. Unless Congress amends the ADEA to expressly prohibit reverse age discrimination claims, the circuit courts are bound to be hopelessly confused now that the Sixth Circuit has authorized reverse discrimination claims.

The Supreme Court is scheduled to decide this issue during the 2003-2004 term. If the Court recognizes certain reverse age discrimination claims based on the plain language of the statute, Congress should re-examine the current state of the ADEA. It has strayed far from its goals. For every claim that presents a case that strays from the purpose of the ADEA, the weaker the statute becomes and the greater chance courts will deny relief to plaintiffs with legitimate causes of action. Furthermore, Congress must examine the data to decide to what extent forty-year-olds should still be considered "old" and in need of protection. Finally, the Wirtz Report clearly saw economically based decisions as an impediment to the employment of older workers. Congress needs to definitively decide to what extent economics should play a role in employment decisions.

Regardless of how the Supreme Court chooses to decide the case, ${ }^{285}$ the Court must guide the lower courts on how to deal with age discrimination. It should strive to articulate the precise differences between age discrimination claims and other forms of discrimination. Because lower courts are unclear about how age discrimination falls into the greater picture of employment discrimination, courts unsuccessfully try to apply a classical discrimination theory used in other types of discrimination to age discrimination.

Karlen v. City Colleges of Chicago, for example, dealt with voluntary early retirement plans before the passage of the Older Worker's Benefit Protection Act ("OWBPA"). ${ }^{286}$ The plan offered incentives for employees aged fifty-five to sixty-nine to retire early. ${ }^{287}$ The incentives were greatest for employees in the middle of this age bracket, but less for employees in the upper and lower range of the age bracket. ${ }^{288}$ After it distinguished age

285. Judging by the Justices' harsh questioning of the plaintiffs's attorney during the November 12 , 2003 oral arguments, one commentator has stated that the Supreme Court appeared "sympathetic ... to the plea of corporate America and the AARP" to overturn the Cline decision. Tony Mauro, Court Engaged in Age Bias Case, Legal Times, Nov. 17, 2003, at 8.

286. See Karlen v. City Colls. of Chicago, 837 F.2d 314 (7th Cir. 1988); see also supra text accompanying notes $12-14$.

287. Karlen, 837 F.2d at 316.

288. Id. 
discrimination from other types of discrimination, Karlen then applied classical discrimination principles to the retirement plan and held that only the oldest employees have a cause of action. ${ }^{289}$ "The futility of such an attempt is immediately apparent when the court asserts that classical principles must be applied without modification, yet that they can also tolerate age-based distinctions within the protected class." ${ }^{290}$ Karlen expressly grants preferential treatment to older workers instead of merely according age a neutral status in employment decisions.

However, if the court is really serious about the application of classical discrimination principles to older workers, how can it tolerate any distinctions based on membership in this category? If the court really wants to apply classical discrimination principles, is it not giving sixty-year olds more favorable treatment than forty year-olds - by allowing them to participate in ERIPs - like saying that lighter skinned African-Americans do not qualify for protections to the same degree as darker skinned African-Americans? ${ }^{291}$

Either Congress intended to give the oldest workers special treatment or they did not. If Congress intended to accord age a neutral status, there should be no age-based distinctions between members of the same protected class. By the passage of the OWBPA, however, Congress has implicitly authorized preference for the oldest workers in some situations. The Supreme Court should clarify whether this preference for the oldest workers always applies or whether classical discrimination principles can be used in certain situations.

If reverse age discrimination claims are ever appropriate, it is when employers arbitrarily treat workers differently. As noted, reverse discrimination claims brought under the ADEA all involve the denial of benefits to "younger older" workers. Karlen, ${ }^{292}$ Schuler v. Polaroid Corp.,${ }^{293}$ Hamilton v. Caterpillar, ${ }^{294}$ and Parker v. Wakelin ${ }^{295}$ all involved some form of an early retirement plan or severance package that granted more benefits to older individuals in order to encourage retirement. The courts all denied relief. As of 1991, the ADEA expressly allows voluntary early retirement incentive plans consistent with the purposes of the Act. ${ }^{296}$ Since at some point an employee's wage compared to his or her productivity makes it unduly

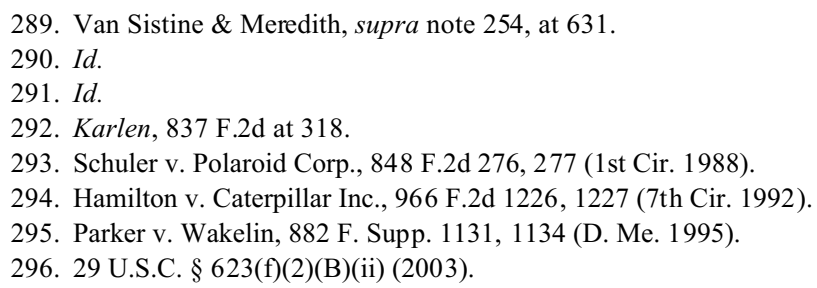


expensive for an employer to continue to employ him or her, it is reasonable that employers should be allowed to induce workers to retire based on their age without giving younger employees the same benefit. If the younger employees work long enough, they eventually would receive the same opportunity.

Other reverse age discrimination claims involve a different theme. Conn v. First Union Bank of Virginia dealt with the discontinuation of a life insurance policy benefit for employees under fifty-five. ${ }^{297}$ In Feigl v. Ecolab, Inc., the employer changed the requirements for obtaining retiree health benefits for certain employees. ${ }^{298}$ Employees were no longer eligible for the benefits unless they met certain requirements based on age and years of service. ${ }^{299}$ Cline involved a change in a collective bargaining agreement. While the employer used to offer full health benefits upon retirement, they now only had to offer full health benefits to employees who were aged fifty or older on July 1, 1997..$^{300}$ These cases involved the denial of a benefit to "younger older" workers that they previously would have been eligible to receive. ${ }^{301}$ Mississippi Power \& Light Co. v. Local Union Nos. 605 \& 985 involved a dispute about a provision of a collective bargaining agreement between the plaintiff, the employer, and the defendants, the labor unions. ${ }^{302}$ If an employee of the plaintiff was disabled, between sixty and sixty-five years of age, and had obtained thirty years of service with plaintiff, the provision allowed the employee to resist any attempt by the plaintiff to transfer him or her to a new work location. ${ }^{303}$

All four cases involved the denial of a benefit to "younger older" workers because of a seemingly arbitrary age limit. In situations such as these, and the absence of express exceptions in the Act, courts should use the approach of

297. Conn v. First Union Bank of Va., No. 94-0901-R, 1995 U.S. Dist. LEXIS 9242, at*2 (W.D. Va. Mar. 17, 1995).

298. Feigl v. Ecolab, Inc., 2003 U.S. Dist. LEXIS 15886, at*1-2 (N.D. Ill. Sept. 9, 2003).

299. $I d$.

300. Cline v. Gen. Dynamics Land Sys., Inc., 296 F.3d 466, 468 (6th Cir. 2002), cert. granted, 123 S. Ct. 1786 (2003).

301. While the employees previously may have been eligible to receive benefits, this does not mean they were entitled to these benefits. See Feigl, 2003 U.S. Dist. LEXIS 15886, at *9. This is an important distinction. It is disturbing that an employer could promise future benefits for many years, only to deny them to some employees right before their moment of vesting simply because they were not a certain age, as is the situation in Cline. However, this is part of the collective bargaining process, and without a clear entitlement to the benefits, there may not be a legal remedy, at least under the ADEA.

302. Miss. Power \& Light Co. v. Local Union Nos. 605 \& 985, Int'1 Bhd. of Elec. Workers, 945 F. Supp. 980, 981 (S.D. Miss. 1996), aff'd without opinion, 102 F.3d 551 (5th Cir. 1996).

303. Id. 
Mississippi Power. Mississippi Power uses 29 C.F.R. § 1625.2(b) and its comments to guide its decision making. Section 1625.2(b) states: "The extension of additional benefits, such as increased severance pay, to older employees within the protected group may be lawful if an employer has a reasonable basis to conclude that those benefits will counteract problems related to age discrimination." 304 The EEOC clarifies this interpretive regulation in their comments and indicates that $\S 1625.2(\mathrm{~b})$ "was never intended to sanction discrimination between individuals entitled to the protections of the act. Rather, the section was intended to permit an employer to extend additional benefits to older members of the protected group in recognition of the problems peculiar to those older individuals." 305 Mississippi Power read the comments to mean that in order for greater benefits to be extended to "older older" workers and not to "younger older" workers, an employer must show why those benefits will counteract discrimination "peculiar" to those individuals. ${ }^{306}$

This approach is not only reasonable, but it is also consistent with the policy implications identified in this Note. Since employment discrimination affects individuals more harshly as they age, and society may desire some rational economically based decisions, this approach gives employers some flexibility to consider age in employment decisions. Importantly, however, an employer could only consider age when it has a reasonable basis to do so. Since this takes all concerns of the ADEA into account, the Supreme Court should adopt this approach for reverse age discrimination claims and delineate what a reasonable basis could be.

\section{Conclusion}

Age discrimination is unlike other forms of discrimination. Congress recognized this during the passage of the ADEA and chose to limit the types of claims that workers can bring. There are policy arguments on each side about the merits of recognizing reverse age discrimination claims. Regardless of policy, however, courts following Cline could hold that the plain language of the ADEA authorizes reverse discrimination claims. Congress should reexamine the ADEA to update it for the realities of today's world. If workers around age forty no longer experience the effects of age discrimination in the 
same way as "older older" workers, reverse discrimination claims should not be cognizable.

If reverse discrimination claims are socially desirable, when an age distinction seems arbitrary, in recognition of the differences between age discrimination and other forms of discrimination, and the possibility that some economically based decisions could benefit more people than they harm, the Supreme Court should adopt the Mississippi Power approach by giving employers the opportunity to explain why granting greater benefits to older workers is reasonable. While reverse age discrimination may not be the soundest policy, it is not absurd, and it certainly is not a simplistic issue. 